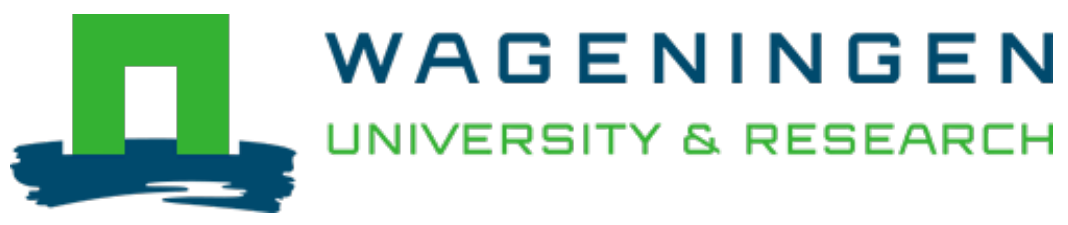

The potential roles of bio-economy in the transition to equitable, sustainable, post fossil-carbon societies : Findings from this virtual special issue

Journal of Cleaner Production

Ingrao, Carlo; Bacenetti, Jacopo; Bezama, Alberto; Blok, Vincent; Goglio, Pietro et al

https://doi.org/10.1016/j.jclepro.2018.09.068

This article is made publicly available in the institutional repository of Wageningen University and Research, under the terms of article $25 \mathrm{fa}$ of the Dutch Copyright Act, also known as the Amendment Taverne. This has been done with explicit consent by the author.

Article 25 fa states that the author of a short scientific work funded either wholly or partially by Dutch public funds is entitled to make that work publicly available for no consideration following a reasonable period of time after the work was first published, provided that clear reference is made to the source of the first publication of the work.

This publication is distributed under The Association of Universities in the Netherlands (VSNU) 'Article $25 \mathrm{fa}$ implementation' project. In this project research outputs of researchers employed by Dutch Universities that comply with the legal requirements of Article $25 \mathrm{fa}$ of the Dutch Copyright Act are distributed online and free of cost or other barriers in institutional repositories. Research outputs are distributed six months after their first online publication in the original published version and with proper attribution to the source of the original publication.

You are permitted to download and use the publication for personal purposes. All rights remain with the author(s) and / or copyright owner(s) of this work. Any use of the publication or parts of it other than authorised under article $25 \mathrm{fa}$ of the Dutch Copyright act is prohibited. Wageningen University \& Research and the author(s) of this publication shall not be held responsible or liable for any damages resulting from your (re)use of this publication.

For questions regarding the public availability of this article please contact openscience.library@,wur.nl 
Review

\title{
The potential roles of bio-economy in the transition to equitable, sustainable, post fossil-carbon societies: Findings from this virtual special issue
}

\author{
Carlo Ingrao ${ }^{\mathrm{a}, \mathrm{b},{ }^{*}, \text { Jacopo Bacenetti }}{ }^{\mathrm{c}}$, Alberto Bezama ${ }^{\mathrm{d}}$, Vincent Blok ${ }^{\mathrm{e}}$, Pietro Goglio ${ }^{\mathrm{f}}$, \\ Emmanuel G. Koukios ${ }^{g}$, Marcus Lindner ${ }^{\mathrm{h}}$, Thomas Nemecek ${ }^{\mathrm{i}}$, Valentina Siracusa ${ }^{\mathrm{j}}$, \\ Anastasia Zabaniotou ${ }^{\mathrm{k}}$, Donald Huisingh ${ }^{1}$ \\ a Department of Economics, University of Foggia, Via Romolo Caggese, 1 - 71121 Foggia, Italy \\ ${ }^{\mathrm{b}}$ Faculty of Engineering and Architecture, Kore University of Enna, Cittadella Universitaria, 94100 Enna, Italy

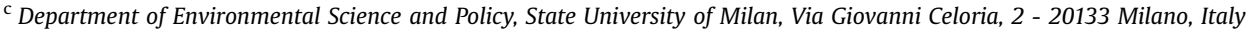 \\ d Bioenergy Department, Helmholtz Centre for Environmental Research - UFZ, Permoserstraße 15 / 04318 Leipzig / Germany \\ e Management Studies, Wageningen University, Hollandseweg 1, 6706 KN, Wageningen, Netherlands \\ ${ }^{\mathrm{f}}$ School of Water, Energy and Environment, Cranfield University, Cranfield, Bedfordshire MK43 OAL, United Kingdom \\ $\mathrm{g}$ Bioresource Technology Unit, School of Chemical Engineering, National Technical University of Athens, Zografou Campus, Athens, GR-15700, Greece \\ ${ }^{\mathrm{h}}$ European Forest Institute, Platz der Vereinten Nationen 7, 53113 Bonn, Germany \\ ${ }^{\mathrm{i}}$ Agroscope, Agroecology and Environment Research Division, LCA Group, 8046 Zurich, Switzerland \\ ${ }^{\mathrm{j}}$ Department of Chemical Science, University of Catania, Viale Andrea Doria 6 - 95125 Catania, Italy \\ ${ }^{\mathrm{k}}$ Biomass Group, Department of Chemical Engineering, Aristotle University of Thessaloniki, Thessaloniki, Greece \\ ${ }^{1}$ Institute for a Secure and Sustainable Environment, University of Tennessee, 311 Conference Centre Building, Knoxville, TN 37996-4134, USA
}

\section{A R T I C L E I N F O}

\section{Article history:}

Received 25 July 2018

Received in revised form

7 September 2018

Accepted 8 September 2018

Available online 9 September 2018

\section{Keywords:}

Agriculture

Forestry

Biomass

Bioenergy

Bio-economy

Comprehensive review

\begin{abstract}
A B S T R A C T
Bio-economy can be defined as an economy where renewable biomasses are produced and converted into value-added materials, chemicals, foods, feeds, fuels and energy: therefore, it represents one valid, reliable way to transition to equitable, sustainable, post fossil-carbon societies. For this reason, it is increasingly gaining attention by scientists and academics worldwide, as is supported by this special issue developed within the Journal of Cleaner Production and presented in this editorial article.

This Virtual Special Issue (VSI) was designed to highlight the importance of academic research in documenting the multiple greening effects that bio-economy has in multiple societal sectors. Therefore, the editors are confident that it will help to create the platform to exchange and to enhance knowledge on the evolving bio-economy. In this context, this editorial was designed to provide an overview of the papers contained in this special issue and to highlight their contributions to the bio-economy within five main research themes: biomass, biomaterials and bioenergy; agriculture; forestry; production and packaging of foods and feeds; and miscellaneous applications. Based upon the analysis of this VSI's papers, the authors found that there is an urgent need for research on: meta-studies of cross-country/ regional interventions, to assess which interventions are more effective; more effective harmonisation solutions of methodological approaches for bio-economy assessments; and finally more interdisciplinary collaboration among technical and social scientists to identify and address the relevant questions for the bio-economy and to exchange and involve academics with all actors of the "innovation pipeline" of the bio-economy.
\end{abstract}

๑) 2018 Elsevier Ltd. All rights reserved.

\footnotetext{
* Corresponding author. Department of Economics, University of Foggia, Via Romolo Caggese, 1 - 71121 Foggia, Italy.

E-mail addresses: carlo.ingrao@unifg.it (C. Ingrao), jacopo.bacenetti@unimi.it (J. Bacenetti), alberto.bezama@ufz.de (A. Bezama),vincent.blok@wur.nl (V. Blok), pietro.goglio@cranfield.ac.uk (P. Goglio), koukios@chemeng.ntua.gr (E.G. Koukios), marcus.lindner@efi.int (M. Lindner), thomas.nemecek@agroscope.admin.ch (T. Nemecek), vsiracus@dmfci.unict.it (V. Siracusa), azampani@auth.gr (A. Zabaniotou), dhuisingh@utk.edu (D. Huisingh).
} 


\section{Contents}

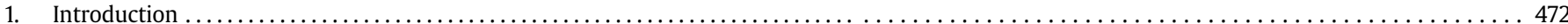

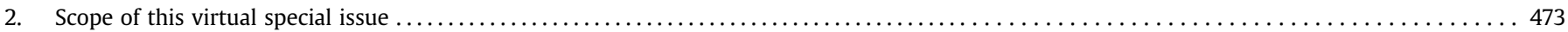

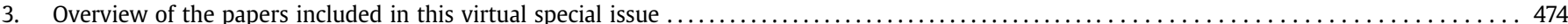

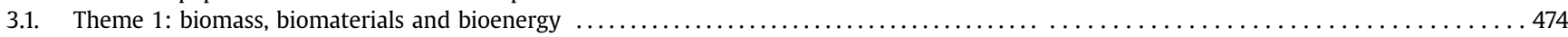

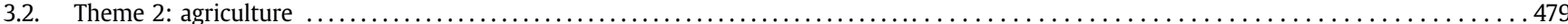

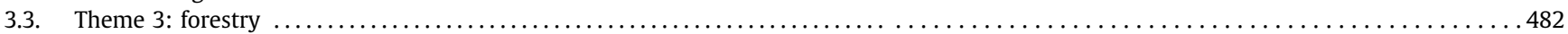

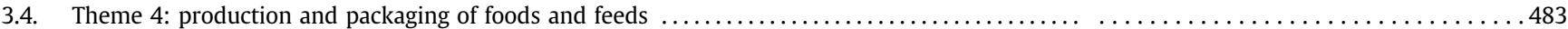

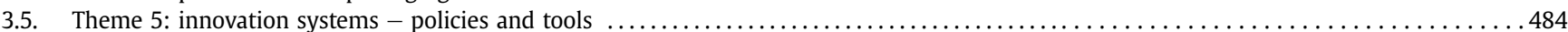

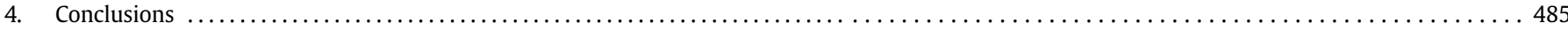

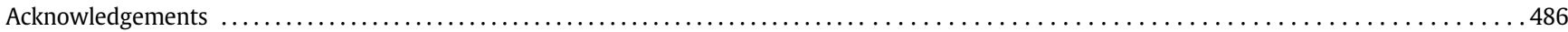

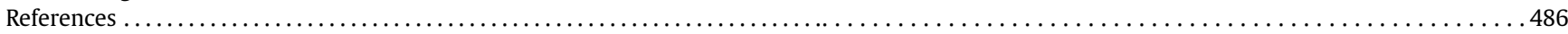

\section{Introduction}

In the current societal system, huge quantities of fossil resources are processed into material and energy commodities to meet society's basic needs, as well as to sustain its health and quality of life levels. Current consumption levels, however, cause resource stock depletion and the emission of carbon dioxide $\left(\mathrm{CO}_{2}\right)$ and other greenhouse gases (GHGs), as well as of other pollutants impacting directly and indirectly, human health and ecosystem quality on a global level. Additionally, the global population is expected to grow to nine billion or more people by 2050: as a result, all societies will be increasingly confronted by many serious environmental challenges, such as biodiversity losses, food and water insecurity, and economic and political disruptions (Huisingh et al., 2015; Rockström et al., 2009). This emphasises the need to face planetary boundaries being exceeded in many ways and locations such as: climate change, water scarcity, depletion of aquifers, rapid deforestation, spreading deserts, erosion of the limited agricultural lands as well as pollution of waters and soils.

Therefore, people of all societies must take responsibilities and actions seriously to accelerate the transition to sustainable, post fossil-carbon economies by sustainable utilisation of renewable biomasses - instead of fossil resources - for production of biomaterials and bioenergy (Bacenetti et al., 2015; Ingrao et al., 2016). According to McCormick and Kautto (2013), this will require a significant shift in socio-economic, political, business, industrial, agricultural, energy and technical systems. In 2014, the European Commission agreed on a new 2030 Framework for climate and energy to achieve a more competitive, secure and sustainable energy system (European Commission, 2014). To that end, two important targets were set in that framework to be: a $40 \%$ cut in GHG emissions compared to 1990 levels; and, at least, a 27\% share of renewable energy consumption (European Commission, 2014).

In this context, the bio-economy can be considered as a possible strategy to achieve those targets, because it promotes:

- utilisation of renewable energy resources, to reduce fossil fuels consumption and resultant GHG emissions;

- wiser systems for natural resource management; and

- improved food security (van Renssen, 2014; Thrän and Bezama, 2017).

This is one main reason why it has been receiving increasing attention from scientists and academics worldwide, as documented by the contents of this bio-economy related special issue (Ingrao et al., 2016) of the Journal of Cleaner Production (JCLP) and as summarised in this editorial article.

Bio-economy is related to and sometimes confused with two other concepts, namely green and circular economy. Green economy is designed at enhancing the functionality and resilience of socio-ecological systems by building upon natural capital; and complementing technical fixes with nature-based solutions (UNEP, 2011). The Circular Economy (CE), on the other hand, is designed for optimising material and energy efficiency through technological development and industrial symbiosis. For this purpose, from a $\mathrm{CE}$ perspective, excessive resource utilisation is minimised by repairing, remanufacturing and reusing the products, as well as by using wastes generated during production and usage of products, into resources for manufacturing secondary raw materials (Ingrao et al., 2018). The CE encompasses all materials, no matter whether they are renewable, fossil or mineral; by contrast, when the focus is upon the renewables, the term bio-economy is used. Bio-economy is part of the green economy but is more centred upon the usage of renewable raw materials and upon the application of research, development and innovation of industrial biotechnology (Scarlat et al., 2015; Aquilani et al., 2018). As a matter of fact, a bioeconomy can be understood as an economy where renewable biomasses are produced and converted into value-added materials, chemicals, foods and feeds, fuels and energy (European Commission, 2012).

Bio-economy is not a revolution in itself: in fact, world economies before the industrial revolution were mainly based upon biomass, and there is a long history and tradition in industrial sectors that are based upon the bio-economy (e.g. the pulp and paper industry). The novelty that the concept of the bio-economy has brought is the objective to achieve higher efficiency in biomass usage, by maximising the added value of the produced goods. For this reason, key aspects for a successful implementation of the bio-economy are and will be based upon appropriate economies of scale for using biomass resources directly and through advanced conversion systems (i.e. the bio-refineries). The latter will be able to produce a broad product range including e.g. biochemicals, pharmaceuticals, bio-textiles, the traditional foods, fibres and wood products (Scarlat et al., 2015).

However, introducing new processes and products into industrial systems and into the markets does not ensure a sustainable bio-economy (Bezama, 2018). Only if the systems are designed and implemented intelligently and responsibly will the bio-economy be able to fulfil the requirements for sustainability from environmental, and socio-economic perspectives (McCormick and Kautto, 
2013; Hildebrandt et al., 2017; Reißmann et al., 2018a). For this purpose, a bio-economy should encompass and highlight the importance of reliable and sustainable innovations to find new growth opportunities in various industrial sectors, being aware of the challenges at the micro- and macro-level (Aquilani et al., 2018; Bezama, 2018; Reißmann et al., 2018b).

Sustainable bio-economies can help to ensure the transition towards low-energy demanding and GHG emitting methods of production and consumption, while building upon innovations to preserve, and increase, productivity and profitability (Pülzl et al., 2014; Huisingh et al., 2015; Szarka et al., 2018).

Another potential, positive effect of a sustainable bio-economy is to generate employment in both urban and rural settings (McCormick and Kautto, 2013; Siebert et al., 2018a), as biomass is virtually ubiquitous, therefore, it is available for both urban and rural populations (Lewandowski, 2015). If adequately implemented, an optimised biomass production, processing and product development system will provide new job and income opportunities through implementation and development of new processes (Lewandowski, 2015; Szarka et al., 2017; Siebert et al., 2018b).

Furthermore, in a sustainable bio-economy, the creation of new non-food markets for agriculture (such as bioenergy) in synergy with existing food markets, and in combination with alternative income sources for farmers, can give rural areas a major boost (McCormick and Kautto, 2013; Szarka et al., 2017; Purkus et al., 2018a).

Therefore, it appears that the opportunities for positive impacts flowing from an advanced bio-economy are immense at environmental, economic, social and ethical levels (McCormick and Kautto, 2013; Bezama, 2016.) Because of these potential benefits, achievement of sustainable bio-economies has been placed high on the agenda in many countries and regions. As reported at the second Global Bio-economy Summit held during April 2018, more than 50 countries, have acknowledged the potential benefits of establishing a holistic, responsible bio-economy and have established dedicated national strategies to implement national bio-economies. This is an increase of 30\% compared with the number, which had committed to bio-economy development in 2015 (Lewandowski, 2015; Philp, 2015; Karliczek, 2018). Such commitments can play crucial roles in the building competitive, resource efficient and low fossil-carbon economies, to accelerate the transition to global sustainable development (de Besi and McCormick, 2015; Huisingh et al., 2015; Scarlat et al., 2015).

However, while the technical potential for the bio-economy is impressive, the challenge is to sustainably increase the scale of biomass production, in parallel with meeting key sustainability goals and ensuring food security for all (McCormick and Kautto, 2013; Bezama, 2018). Although current developments in the bioeconomy are promising and can accelerate the transition from fossil-carbon based economies, there is still a long way to go (Bosman and Rotmans, 2016).

This is mainly because it seems that bio-economy research studies are generally focussed upon the technical issues of biomass valorisation, and pay little attention on sustainable production and management of the genetic, soil and water resources for the short and long-term, upon which the bio-economy must be built upon. Furthermore, in spite of good political intentions to boost the bioeconomy, often implementation of measures for achieving the goals into practice is hindered by lacking infrastructures and/or by the appearance of negative effects within the bio-economy system (Hildebrandt et al., 2017). This is normally due to lack of a systematic approach to appraise the real status quo of the bioeconomy at national and regional levels and therefore, failure to adequately understand the social, psychological, political and economic barriers to transforming present societies into the new types of societies that are needed to achieve sustainable bioeconomies.

Implementers of a holistic, responsible, sustainable bioeconomy must consider a broad spectrum of applications of biological sciences and their associated technologies for sustainable production and utilisation of quality and sustainable products and services in various fields of the economy, for today and the future while also ensuring food security for expanding human populations (Ingrao et al., 2016; Winkel, 2017). The changes that will be required will have to innovatively address the normative and socioeconomic barriers as well as the technological and ecological challenges to making the urgently needed transition to post-fossil carbon bio-economies.

The transition to bio-economies must address the ethical issues of inter-and intra-generational equity (Murray et al., 2017). However, in current research and policy-making processes, these barriers are seldom considered (Geissdoerfer et al., 2016). Another barrier for the needed transformations is the lack of customer demand for bio-based products (Verbong and Geels, 2007) and that the concepts, visions, and processes of the interconnections between the biosphere and the economic sphere in the bio-economy are unclear (Zwier et al., 2015).

Finally, an important aspect of the value and strategic attraction of a sustainable bio-economy for policy and decision-makers is its potential 'bio-greening' impacts upon policies, education, products, processes, and systems. The growing bio-economy could have greening effects upon agricultural, horticultural and aqua-cultural, food and feed supply chains, and in reforestation and sustainable management of all resources. Winkel (2017), warned that policies for transformation to bio-economies must address the trade-offs between bio-economy development and the preservation of forestry quality and sustainability. This will also be true for sustainable management and usage of all bio-resources.

\section{Scope of this virtual special issue}

This Virtual Special Issue (VSI) was developed based upon the concern that the transitions stated in the previous paragraphs must be properly envisioned, designed, tested, and implemented to ensure sustainable production, distribution and consumption of biomass for production of food as well as materials and energy to help to accelerate the transition to post-fossil carbon societies. If properly made, the transitions will help to catalyse improvements in technological quality, socio-economic equity and environmental sustainability in holistically integrated ways, while reducing the climate change impacts (Ingrao et al., 2016).

In this context, the central purpose of this bio-economy related VSI was to highlight the importance of the academic research in documenting ways for bio-based concepts, tools, technologies, education and policies to play increasingly central roles for accelerating the transition to equitable, sustainable, post-fossil carbon societies.

The VSI was designed and developed to promote scientific research and dialogue about policies, technologies, processes, scaled-up applications, monitoring, reporting and education upon all dimensions of the transition to societies based upon integrated, equitable, sustainable bio-economies; and support policy makers, technology developers and producers, educators and researchers, financial systems managers, entrepreneurs, farmers, fishers, and foresters for development and usage of globally-interconnected information exchange networks designed to foster transitions to sustainable bio-economies at global scales.

Finally, this editorial was developed to provide an overview of the papers of the contributions of the articles of this VSI to the bio- 
economy field in five themes:

- Theme 1: Biomass, Biomaterials and Bioenergy

- Theme 2: Agriculture

- Theme 3: Forestry

- Theme 4: Production and Packaging of Foods and Feeds

- Theme 5: Innovation systems - policies and tools

\section{Overview of the papers included in this virtual special issue}

This VSI attracted huge interest and attention from the scientific community worldwide with the submission of more than 100 papers, which exceeded expectations of the guest editorial team members. Following the JCLP's responsibility all submissions were subjected to in-depth, constructive reviews, with the objective of improving the quality of the articles. A total of 68 papers were accepted for publication in this VSI, which were submitted from all over the world, as presented in Fig. 1, with authors from Italy, Germany and Spain having submitted $50 \%$ of the accepted papers.

In this VSI, those papers were grouped into five research themes and were reviewed to highlight the main objectives and findings of each of them. Information on the titles of the papers within each theme is presented in Table 1.

Theme one, Biomass, Biomaterials and Bioenergy, was addressed in twenty-six papers, making this theme the most addressed within this VSI. Out of the accepted papers, twenty-three addressed the sub-topic of "Biomass and Bioenergy", and three papers addressed the sub-topic "Biomaterials." Nineteen papers addressed theme two, Agriculture, by discussing the multiple key roles that bio-economy can play - and that can be assessed and improved - for greening the agricultural sector. Fewer papers addressed themes three, four and five $(10,8$ and 5 papers, respectively).

The following sections were designed to summarise the key findings and discussions of the individual papers of this VSI. For more details, the readers are referred to the related papers.

\subsection{Theme 1: biomass, biomaterials and bioenergy}

Authors of several papers analysed biomass, biomaterials and bioenergy regarding their quality and sustainability aspects in a bio-economy perspective.

In their contribution, Abdulrahman and Huisingh (2018) analysed the energy system in Egypt and evaluated the roles that biomass could play as a resource for stabilising it and making the electrical power system more sustainable. They used a multicriteria decision analysis approach to assess several technical alternatives in short, medium and long-term scenarios, through which they provided interesting recommendations for achieving the country's renewable energy generation target for 2022 .

Following the biomass investigation issue, Millinger and Thrän (2018) shed light on the following research questions: (i) What costs and cost developments can be expected under different scenarios for energy crops in Germany? And (ii) How do these feedstock cost developments affect the competitiveness of biofuels? Using a myopic, recursive, dynamic bottom-up, least-cost simulation model that included endogenous technological learning, they assessed the competition between different technology options, for fulfilling a set demand of biofuels in different scenarios. Their results confirmed that feedstock costs are by far the most important determining factor of the future costs of biofuels, which makes investments in biofuels in general and advanced biofuels in particular a highly risky endeavour. The share of levelized capital costs of the total biofuel costs were found to substantially decrease with increasing feedstock costs. As feedstock cost developments are out of the control of investors, this inhibits investments and R\&D efforts (except for conversion efficiency improvements). This is characteristic for any usage of biomass, in stark contrast to other renewable options such as wind and solar photovoltaics, which

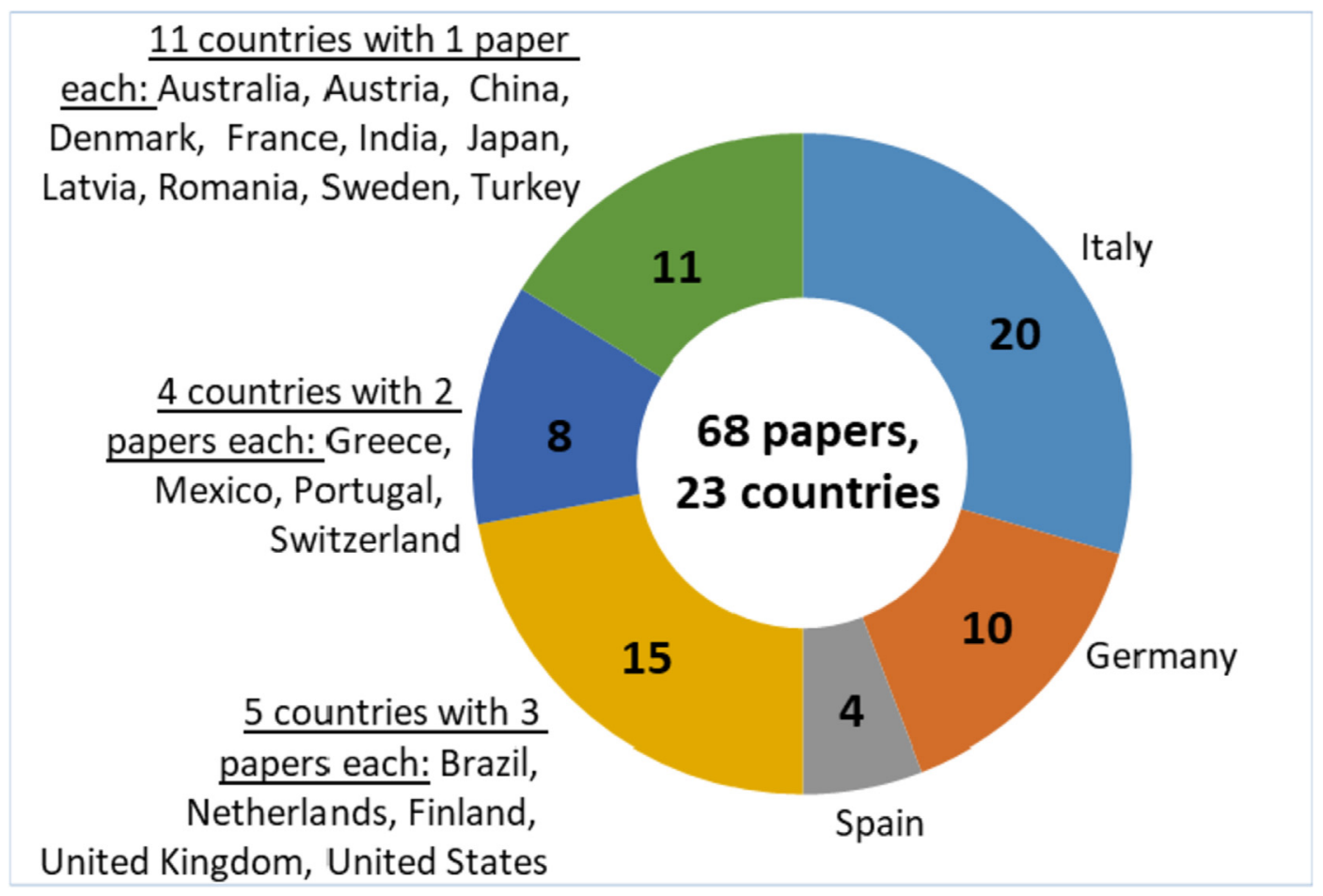

Fig. 1. The figure shows the geographical distribution of the 68 accepted papers of this VSI, organised according to the affiliation of the first author. 
Table 1

The authors and titles of the sixty-eight articles, listed alphabetically by the surname of the first author.

\begin{tabular}{|c|c|c|c|c|c|c|}
\hline \multicolumn{2}{|l|}{ Article reference } & \multicolumn{5}{|c|}{ Research theme } \\
\hline Authors & Title & 1 & 2 & 3 & 4 & 5 \\
\hline $\begin{array}{l}\text { Abdulrahman and } \\
\text { Huisingh (2018) }\end{array}$ & The role of biomass as a cleaner energy source in Egypt's energy mix & $\mathrm{x}$ & & & & \\
\hline Ahmed et al. (2018) & Transforming organic prawn farming in Bangladesh: Potentials and challenges & & & & $\mathrm{x}$ & \\
\hline Aiello et al. (2018) & A decision support system based on multisensor data fusion for sustainable greenhouse management & & $\mathrm{x}$ & & & \\
\hline $\begin{array}{l}\text { Alemán-Nava et al. } \\
\text { (2018) }\end{array}$ & $\begin{array}{l}\text { Biotechnological revalorisation of Tequila waste and by-product streams for cleaner production-A } \\
\text { review from bio-refinery perspective }\end{array}$ & $\mathrm{x}$ & & & & \\
\hline Alexiades et al. (2018) & $\begin{array}{l}\text { Sugar beet ethanol (Beta vulgaris L.): A promising low-carbon pathway for ethanol production in } \\
\text { California }\end{array}$ & $\mathrm{x}$ & & & & \\
\hline
\end{tabular}

Aquilani et al. (2018)

The challenging transition to bio-economies: Towards a new framework integrating corporate

Bais-Moleman et al. (2018)

Balata and Tola (2018)

Blumberga et al. (2018)

Boscaro et al. (2018)

Bragaglio et al. (2018)

Brunet-Navarro et al. (2018)

Cerveira et al. (2018)

Challis et al. (2018)

Cheng et al. (2018)

Corrado et al. (2018)

Crenna et al. (2018)

Dunnigan et al. (2018),

Egelyng et al. (2018)

Ferrari et al. (2018)

Fiore et al. (2018a)

Fiore et al. (2018b)

Freire (2018)

Gallo et al. (2018)

Giungato et al. (2018)

Goglio et al. (2018a)

Goglio et al. (2018b)

González-García et al. (2018)

Hagman et al. (2018)

Hou et al. (2018)

Hurmekoski et al.

(2018)

Husmann et al. (2018)

Jürges and Hansjürgens (2018)

Karabulut et al. (2018)

Keshavarz Afshar et al.

(2018)

Koukios et al. (2018)

Lopes et al. (2018a)

Lopes et al. (2018b)

Lovarelli et al. (2018)

Lozano and Lozano

(2018),

Maalouf et al. (2018)

Martins et al. (2018)
Assessing wood use efficiency and greenhouse gas emissions of wood product cascading in the European Union

Cost-opportunity analysis of the use of Posidonia oceanica as a source of bio-energy in tourism-oriented territories. The case of Alghero

System dynamics model of a biotechonomy

Evaluation of the energy and greenhouse gases impacts of grass harvested on riverbanks for feeding anaerobic digestion plants

Environmental impacts of Italian beef production: A comparison between different systems.

Effect of cascade use on the carbon balance of the German and European wood sectors

Gas permeation applied to biogas upgrading using cellulose acetate and polydimethylsiloxane membranes

Human factors in dairy industry process control for energy reduction

Building a sustainable development model for China's poverty-stricken reservoir regions based on system dynamics.

Systematic analysis of secondary life cycle inventories when modelling agricultural production: A case study for arable crops

Natural biotic resources in LCA: Towards an impact assessment model for sustainable supply chain management

Production of biochar from rice husk: Particulate emissions from the combustion of raw pyrolysis volatiles

Cascading Norwegian co-streams for bioeconomic transition

Effects of grape quality on the environmental profile of an Italian vineyard for Lambrusco red wine production

Mitigation of global warming impact of fresh fruit production through climate smart management

GHG and cattle farming: CO-assessing the emissions and economic performances in Italy

Enhancing innovation through behavioural stimulation: The use of behavioural determinants of

innovation in the implementation of eco-innovation processes in industrial sectors and companies

Clustering analysis of environmental emissions: A study on Kyoto Protocol's impact on member countries

Sustainable domestic burning of residual biomasses from the Friuli Venezia Giulia region

Development of Crop.LCA, an adaptable screening life cycle assessment tool for agricultural systems: A

Canadian scenario assessment.

A comparison of methods to quantify greenhouse gas emissions of cropping systems in LCA

Environmental assessment of biorefinery processes for the valorisation of lignocellulosic wastes into oligosaccharides

The role of biogas solutions in sustainable biorefineries

Stakeholder perceptions of manure treatment technologies in Denmark, Italy, the Netherlands and

Spain.

Long-term targets for green building: Explorative Delphi backcasting study on wood-frame multi-story construction in Finland

Biomass functions and nutrient contents of European beech, oak, sycamore maple and ash and their meaning for the biomass supply chain

Soil governance in the transition towards a sustainable bioeconomy - A review

A proposal for integration of the ecosystem-water-food-land-energy (EWFLE) nexus concept into life cycle assessment: A synthesis matrix system for food security

Agronomic effects of urease and nitrification inhibitors on ammonia volatilisation and nitrogen

utilisation in a dryland farming system: Field and laboratory investigation

Targeting sustainable bioeconomy: A new development strategy for Southern European countries. The

Manifesto of the European Mezzogiorno

Chitin production from crustacean biomass: Sustainability assessment of chemical and enzymatic processes.

Combining cleaner production and life cycle assessment for reducing the environmental impacts of irrigated carrot production in Brazilian semi-arid region

Beyond the Water Footprint: a new framework proposal to assess freshwater environmental impact and consumption

Assessing the potential sustainability benefits of agricultural residues: Biomass conversion to syngas for energy generation or to chemicals production.

An energy and Carbon Footprint assessment upon the usage of hemp-lime concrete and recycled-PET façades for office facilities in France and Italy 
Table 1 (continued)

\begin{tabular}{|c|c|c|c|c|c|c|}
\hline \multicolumn{2}{|l|}{ Article reference } & \multicolumn{5}{|c|}{ Research theme } \\
\hline Authors & Title & 1 & 2 & 3 & 4 & 5 \\
\hline & $\begin{array}{l}\text { 2MBio, a novel tool to encourage creative participatory conceptual design of bioenergy systems }- \text { The } \\
\text { case of wood fuel energy systems in south Mozambique }\end{array}$ & & & & & \\
\hline Merli et al. (2018) & $\begin{array}{l}\text { Sustainability experiences in the wine sector: toward the development of an international indicators } \\
\text { system }\end{array}$ & & $\mathrm{x}$ & & & \\
\hline $\begin{array}{l}\text { Mihai and Ingrao } \\
\text { (2018) }\end{array}$ & $\begin{array}{l}\text { Assessment of biowaste losses through unsound waste management practices in rural areas and the role } \\
\text { of home composting }\end{array}$ & $\mathrm{x}$ & & & & \\
\hline $\begin{array}{l}\text { Millinger and Thrän } \\
\text { (2018) }\end{array}$ & $\begin{array}{l}\text { Biomass price developments inhibit biofuel investments and research in Germany: The crucial future } \\
\text { role of high yields }\end{array}$ & $\mathrm{x}$ & & & & \\
\hline Mustalahti (2018) & $\begin{array}{l}\text { The Responsive Bioeconomy: The need for inclusion of citizens and environmental capability in the } \\
\text { forest-based bio-economy }\end{array}$ & & & $\mathrm{x}$ & & \\
\hline Nakano et al. (2018) & Greenhouse gas emissions from round wood production in Japan & & & $\mathrm{x}$ & & \\
\hline Noya et al. (2018) & Environmental impacts of the cultivation-phase associated with agricultural crops for feed production & & & & $\mathrm{x}$ & \\
\hline Pergola et al. (2018) & $\begin{array}{l}\text { A combined assessment of the energy, economic and environmental issues associated with on-farm } \\
\text { manure composting processes: Two case studies in South of Italy }\end{array}$ & $\mathrm{x}$ & & & & \\
\hline Polimeni et al. (2018) & $\begin{array}{l}\text { Understanding consumer motivations for buying sustainable agricultural products at Romanian farmers } \\
\text { markets }\end{array}$ & & $\mathrm{x}$ & & & \\
\hline Presciutti et al. (2018) & Energy and exergy analysis of glycerol combustion in an innovative flameless power plant & $\mathrm{x}$ & & & & \\
\hline Purkus et al. (2018b) & $\begin{array}{l}\text { Towards a sustainable innovation system for the German wood-based bioeconomy: Implications for } \\
\text { policy design }\end{array}$ & $\mathrm{x}$ & & & & \\
\hline $\begin{array}{l}\text { Ramcilovic-Suominen } \\
\text { and Pülzl (2018) }\end{array}$ & Sustainable development - A 'selling point' of the emerging EU bioeconomy policy framework? & & & $\mathrm{x}$ & & \\
\hline Rota et al. (2018) & Assessing the level of collaboration in the Egyptian organic and fair-trade cotton chain & & $\mathrm{x}$ & & & \\
\hline Scheiterle et al. (2018) & $\begin{array}{l}\text { From commodity-based value chains to biomass-based value webs: The case of sugarcane in Brazil's } \\
\text { bioeconomy }\end{array}$ & $\mathrm{x}$ & & & & \\
\hline Senyolo et al. (2018) & $\begin{array}{l}\text { How the characteristics of innovations impact their adoption: An exploration of climate-smart } \\
\text { agricultural innovations in South Africa }\end{array}$ & & $\mathrm{x}$ & & & \\
\hline Shi et al. (2018) & Consumers' climate-impact estimations of different food products & & $\mathrm{x}$ & & & \\
\hline Siebert et al. (2018c) & $\begin{array}{l}\text { Social life cycle assessment indices and indicators to monitor the social implications of wood-based } \\
\text { products }\end{array}$ & & & $\mathrm{x}$ & & \\
\hline Simha et al. (2018) & $\begin{array}{l}\text { Continuous urea-nitrogen recycling from human urine: A step towards creating a human excreta-based } \\
\text { bio-economy }\end{array}$ & & $\mathrm{x}$ & & & \\
\hline Spierling et al. (2018) & Bio-based plastics - A review of environmental, social and economic impact assessments & $\mathrm{x}$ & & & & \\
\hline $\begin{array}{l}\text { Thonemann and } \\
\text { Schumann (2018) }\end{array}$ & $\begin{array}{l}\text { Environmental impacts of wood-based products under consideration of cascade utilisation: A systematic } \\
\text { literature review }\end{array}$ & & & $\mathrm{x}$ & & \\
\hline Tricase et al. (2018) & $\begin{array}{l}\text { A comparative Life Cycle Assessment between organic and conventional barley cultivation for } \\
\text { sustainable agriculture pathways }\end{array}$ & & $\mathrm{x}$ & & & \\
\hline $\begin{array}{l}\text { Valente and Chaves } \\
\text { (2018) }\end{array}$ & Perceptions and valuation of GM food: A study on the impact and importance of information provision & & $\mathrm{x}$ & & & \\
\hline $\begin{array}{l}\text { Varela-Candamio et al. } \\
\text { (2018) }\end{array}$ & $\begin{array}{l}\text { The role of public subsidies for efficiency and environmental adaptation of farming: A multi-layered } \\
\text { business model based on functional foods and rural women }\end{array}$ & & $\mathrm{x}$ & & & \\
\hline Vaskan et al. (2018) & $\begin{array}{l}\text { Techno-economic and life-cycle assessments of biorefineries based on palm empty fruit bunches in } \\
\text { Brazil }\end{array}$ & $\mathrm{x}$ & & & & \\
\hline Zabaniotou et al. (2018) & $\begin{array}{l}\text { Taking a reflexive TRL3-4 approach to sustainable use of sunflower meal for the transition from a mono- } \\
\text { process pathway to a cascade biorefinery in the context of Circular Bioeconomy }\end{array}$ & $\mathrm{x}$ & & & & \\
\hline Zucali et al. (2018) & $\begin{array}{l}\text { Environmental impact assessment of different cropping systems of home-grown feed for milk } \\
\text { production. }\end{array}$ & & & & $\mathrm{x}$ & \\
\hline Zucaro et al. (2018) & $\begin{array}{l}\text { Effects of urea-fertilisation rates on the environmental performance of giant reed lignocellulosic } \\
\text { feedstock produced for biorefinery purpose }\end{array}$ & $\mathrm{x}$ & & & & \\
\hline
\end{tabular}

have no operational resource costs and must be considered when designing policy for any sector of the bio-economy.

About technology application, Balata and Tola (2018) tackled the issue of using Posidonia oceanica, commonly known as seagrass, as substrate for anaerobic digestion. Main reasons for this study stands in the fact that large Posidonia leaves deposits on the beaches generate some foul odour-derived inconveniences and reduce usability and the untidy appearance of the beaches themselves, so negatively affecting local tourism activities. So, though further research is needed, the value of this contribution was not only the technical aspects of the analysis, but also the analysis of the implications of such biomass utilisation for regions which are predominantly sustained by tourism activities. As a matter of fact, the authors concluded that the usage of Posidonia oceanica is potentially interesting as a resource for biogas production at least from an economic and social perspective. As also clarified by Balata and Tola, further research is required and should be focussed on investigating: available biomass quantities; biogas yield of Posidonia oceanica on an industrial scale; available co-digestion biomasses; biodiversity issues; and environmental impacts.

In another study, Giungato et al. (2018) assessed the efficiency of the combustion process and the emissions of selected pollutants from domestic burning of different biomass types. Their results not only allow identified potential environmental drawbacks arising from residual biomass burning, but they also provided primary experimental measurements data, which may be of interest for scientists, company owners, energy managers, and policy-makers.

Residual biomass from agriculture and forestry can be converted into synthesis gas to generate either energy or chemicals: these two options were investigated by Lozano and Lozano (2018) through ecoefficiency-based assessments. The authors considered one ton of residual pecan nut shell residue per hour to estimate the material flow of chemicals that could be produced, as well as the power that could be generated through residual biomass gasification. Two alternate routes were addressed and compared by the authors: (1) gasification with air, which renders a gas stream with hydrogen, carbon monoxide, carbon dioxide, methane and other hydrocarbons, as well as nitrogen; and (2) gasification with steam, where 
residual biomass is used as fuel, rendering a gas stream like the first route, but without nitrogen.

Through their study, the authors highlighted that eco-efficiency can be used as a decision-making indicator to select more sustainable transformation processes through combinations of technical, economic, environmental, social issues. This can lead, in turn, to more reliable and sustainable ways of natural resources exploitation, thereby helping to accelerate the transition to post-fossil carbon, sustainable societies.

Furthermore, agricultural by-products, and other residual biomass streams, can be subjected to a decentralised conversion into energy and value-added products, such as the biochar. However, fuel properties are characterised by variability: hence, as documented by Dunnigan et al. (2018), when they have high ash contents, such as rice husk, their direct combustion may suffer from increased fouling and slagging issues with resultant high particulate matter (PM) emissions. Combustion of the raw pyrolysis volatiles (bio-oil and synthesis gas (syngas) mixtures) produced from pyrolysis with the inherent separation of ash in the biochar may potentially mitigate these issues (Dunnigan et al., 2018). In this context, Dunnigan et al. (2018) addressed and estimated PM emissions from the combustion of the raw pyrolysis volatiles derived from the pyrolysis of rice husk at a laboratory scale; for this purpose, they utilised a combined pyrolysis and combustion facility.

Based upon results from their research, it can be concluded that bio-oil dominated the higher heating value of the raw pyrolysis volatiles produced at low pyrolysis temperatures. The combustion of such raw pyrolysis volatiles with high bio-oil content substantially increased the production of $\mathrm{PM}_{10}$ and $\mathrm{PM}_{2.5}$. A linear dependence was observed between PM emissions and bio-oil fraction in the raw pyrolysis volatiles. But if the pyrolysis-combustion process, with $>96 \%$ of the ash retained in biochar prior to combustion approach is used, the PM emissions are less than when the direct combustion pathway was used (Dunnigan et al., 2018).

In the biorefinery field, Hagman et al (2018) analysed the role of biogas technologies as part of sustainable biorefineries. They found that biogas solutions can make biorefineries more sustainable and competitive and could make the biorefinery system more resilient and versatile.

This is in line with the findings of Zabaniotou et al. (2018) who provided experimental Proof of Concept (laboratory research) of a sunflower biorefinery by exploring manufacturing of various products by physical and biological processes and pyrolysis. Their study highlighted the biorefinery complexity and formulated alternative pathways for the sustainable sunflower valorisation, by taking a reflexive approach on the utilisation of sunflower meal (by-product) derived from the industrial sunflower oil production, designed to support the transition from a mono-product pathway to a multi process-multi products cascade biorefinery. Their study demonstrated that a sunflower-meal cascade refining concept is feasible and resulted in production of antioxidants, protein isolate, biochar, bioenergy carriers (pyro-oil and pyro-gas) and poly(3hydroxybutyrate) and microbial oil.

Cerveira et al. (2018) investigated the membrane gas permeation potential for biogas upgrading. They conducted research to evaluate the performance of membranes made of two polymers, cellulose acetate and polydimethylsiloxane (PDMS), for $\mathrm{CO}_{2}$ removal. They found that $\mathrm{CO}_{2}$ caused membrane plasticisation, mainly because the higher the $\mathrm{CO}_{2}$ content is in the mixture, the higher the plasticisation is, so leading to higher permeability for both $\mathrm{CO}_{2}$ and $\mathrm{CH}_{4}$.

Through their study, the authors have documented that it is possible to produce biomethane from biogas using commercially available gas permeation membranes, by minimising $\mathrm{CH}_{4}$ loss through the correct process design, but considering the high plasticisation effect of the carbon dioxide on the glassy polymer.

Further in the biorefinery field, Vaskan et al. (2018) performed comparative assessments, based upon techno-economic and environmental issues, of two conversion scenarios of palm, 'Empty Fruit Bunches' (EFB) residue into ethanol, heat and power, and cattle feed. Based upon their research, the scenarios were: the EFB 'feedfuel' (EFB FF) scenario, which produced fuel ethanol and syrup from C5 sugars as a cattle feed supplement; and the EFB 'only fuel' (EFB $\mathrm{OF})$ scenario, which produced only ethanol fuel as the main product. For both scenarios, significant benefits were documented by the authors in terms of reduced climate change impacts and reduced fossil fuel depletion in comparison with relevant reference systems. However, the reduced economic prospects and increased environmental impact levels associated with toxicity and eutrophication led to big concerns with the implementation of small and medium scale biorefineries. Analysing absolute results for both scenarios, the conclusion was that the EFB OF scenario has a better economic prospect but worse results for climate change, and human toxicity impacts than the EFB FF scenario. This is mainly because, in the EFB OF scenario, a dilute acid based pre-treatment is used: this method provides larger consumption of chemicals, though it enables a higher recovery of soluble pentoses (C5) while preparing cellulose for an easier enzymatic hydrolysis. According to the authors, the different economic performance was due to the market advantages of fuel ethanol in comparison to cattle feed based upon C5 syrup. Therefore, the authors recommended further investigations are needed on the conversion of EFB into high valueadded chemicals to improve the economic and environmental performance of such projects.

Alemán-Nava et al (2018) performed a review from a biorefinery perspective considering the biotechnological revalorisation of the different waste and by-products arising from the production process of tequila. The authors pointed out that agave leaves, mainly composed of cellulose, hemicellulose, and lignin, could potentially be utilised: as a sugar source for animal feed or for alcohol production; as a fibre source for paper products; or as a substrate for enzyme production. Agave bagasse could be suitable as animal feed or for fibre board production, composting as well as for bioethanol production.

In another study, Alexiades et al. (2018) determined the carbon intensity rate of ethanol produced from sugar beets cultivated in California's San Joaquin Valley and converted to ethanol in a simulated, state-of-the-art biorefinery utilising anaerobic digestion of process residues and gasification of locally-sourced agricultural residues to reduce energy demand and GHG emissions from fossilbased natural gas and electricity consumption. They found potential improvements for closing loops on process residues, energy, water, and nutrient flows for the entire system.

Presciutti et al. (2018) performed an energy and exergy analysis of the combustion of biodiesel-derived glycerol in an innovative oxy-burner located in the South of Italy. The study was conducted to the search for and development of new technologies for glycerol exploitation through a cascade process that improves quality and sustainability of biodiesel supply chains. Furthermore, the exergy analysis was performed to determine the maximum performance of the system and to identify where exergy losses were generated. Based upon their results, better performance of the industrial plant was obtained compared to traditional fossil fuels combustors, thereby contributing further to the energy output of the biodiesel production chain.

According to the authors, glycerine was found to be technologically, energy/exergy, and environmentally feasible for usage as biofuel for energy production, with performance comparable to 
fossil fuels, as well as with avoided production of pollutants and risk of detonation.

This is because, in agreement with the subject literature, glycerine combustion is essentially a carbon-free process with respect to conventional fuels, as the emitted $\mathrm{CO}_{2}$ was previously captured by the vegetation, and the additional $\mathrm{CO}_{2}$ emissions by "upstream" activities are similar for fossil fuels and glycerine.

So, it can be concluded that the energy exploitation of the glycerol enhances therefore the added value of the biodiesel production chains, so contributing to increased sustainability of bioeconomies.

Martins et al. (2018) proposed a novel tool for participatory conceptual design of bioenergy systems: 2MBio: a metamodel to support the conceptual design of bioenergy systems. According to the authors, 2MBio offers a visual, explicit and formal platform to represent and describe basic design elements (DEs) which are necessary and sufficient for generating comprehensive and meaningful design specification for any bioenergy system. The $2 \mathrm{MBio}$ is user-friendly, non-normative, non-prescriptive and effectively allows a wide range of actors to develop comprehensive, meaningful, contextualised conceptual specifications of wood fuel energy systems (Martins et al., 2018). Based upon a case study in Mozambigue, the authors documented, ways 2MBio can effectively promote creative conceptual design of bioenergy systems.

Pergola et al. (2018) investigated manure treatment in two processing plants by assessing the energy, economic and environmental issues related to on-farm manure composting. From the combined application of Life Cycle Assessment (LCA), energy analysis and Life Cycle Cost Analysis (LCCA), they concluded that composting can reduce negative environmental impacts of manure management and can solve the problem of manure surpluses of livestock farming.

In a related study, Hou et al. (2018) analysed stakeholder perceptions of manure treatment technologies and the impacts on their adoption. Using results from a survey of various stakeholders in four European countries, they identified governmental regulations as a key driver to stimulate improvements in manure management technology adoption, and economic factors as key barriers in the adoption of improved manure management technologies. Slurry separation and anaerobic digestion were documented to have the best potential for adoption, although regional differences must be considered.

Mihai and Ingrao (2018) investigated unsound waste management practices in rural areas, based on the case of Romania. They explored four scenarios of waste management in rural areas by documenting GHG emissions of home composting, dumps and landfills, and they highlighted the role of home composting in combatting the biowaste losses in wild dumps. They concluded that policy-makers should stimulate home composting in plastic bins to develop more sound waste management practices in rural areas.

Lopes et al. (2018a) investigated biomasses from fishing practices. The objective of their work was to compare the sustainability of the chemical and enzymatic processes for chitin production at a pilot scale. Interestingly, the study included not only a technoeconomic and environmental assessment, but also a human health risk assessment to investigate product safety. Results showed that the enzymatic process could be a good alternative that should be considered for chitin extraction, especially when water recovery is also employed.

Scheiterle et al. (2018) explored the links within and between value chains, identified synergies among technologies and evaluated innovations that make efficient use of the new biomass routes in the sugarcane sector in Brazil. For this purpose, they used the "biomass-based value web" concept as an analytical approach. They concluded that Brazil must overcome hurdles and create incentives to foster innovation. Among other aspects, the simplification of the bureaucratic system and establishment of a transparent legal system, are needed. Their study, although it was performed for a specific pathway within the bio economy, has the value as a systematic method to identify bottlenecks for regions and countries to improve their conditions for helping to expand implementation of the bio economy in their regions also.

In regard to innovation, Purkus et al (2018b) analysed the roles policies can play in shaping an innovation system that enables renewable resource-based technologies to progress along the learning curve, while identifying and fostering bio-economy pathways with favourable environmental characteristics and with a high degree of social acceptance. They concluded that the transition to a bio-economy is characterised by a high degree of uncertainty and complexity, making the design of demand-pull policies particularly challenging.

Boscaro et al. (2018) assessed the energy and GHG balance of biogas production using grass harvested upon riverbanks in Northern Italy. They performed an energy analysis using the $\mathrm{Cu}-$ mulative Energy Demand method (CED), and the GHG balance of grass $\mathrm{AD}$ was calculated based on $\mathrm{CO}_{2}$ equivalents. Two different supply systems were evaluated to determine the better supply chain for this feedstock. Special attention was given to the logistical aspects of the process. Considering a biomass yield of $4.8 \mathrm{t}$ of dry matter ha $a^{-1} y^{-1}$, the AD of grass can reduce fossil energy usage of 6.4-7.0 GJ ha ${ }^{-1}$ and a reduction of fossil-carbon-based GHG equivalent emissions of about $181-233 \mathrm{t} \mathrm{CO}_{2} \mathrm{ha}^{-1}$ depending upon logistical details of raw materials transportation to the processing facility.

Zucaro et al. (2018) performed an LCA analysis that was designed to investigate the environmental constraints of Arundo donax L. (giant reed) feedstock cultivation in Mediterranean context. With regard to the crop being produced, different levels of nitrogen fertilisation were considered: 50 and $100 \mathrm{~kg} \mathrm{ha}^{-1}$ of $\mathrm{N}$ as urea (low input- LI and high input- HI, respectively). The Functional Unit (FU) was set to be $1 \mathrm{~kg}$ total dry biomass produced assuming a 15-year crop life cycle. The cumulative impacts throughout the assumed 15-year crop lifetime were assessed on the basis of specific assumptions about long-term farm management and crop yield patterns.

With respect to the cultivation with high fertilisation (HI), the $\mathrm{LI}$ giant reed cultivation showed lower environmental impacts due to the reduced up-stream and direct field emissions linked to urea application. On average, considering all the evaluated impact categories, LI impacts were found to be $24 \%$ lower than $\mathrm{HI}$ impact. Crop yield was a key driving parameter and the lower biomass productivity under $\mathrm{N}$ low input management partially counteracted the benefits of the lower fertilisation rates.

Regarding woody biomass, Husmann et al. (2018) researched different deciduous trees to develop biomass data for tree species like European beech $\left(T_{A}\right)$, oak $\left(T_{B}\right)$, sycamore $\left(T_{C}\right)$ and ash $\left(T_{D}\right)$, by means of regression analysis, using data gathered in Germany. For this purpose, 139 trees of those species were destructively sampled, as follows: $37 \mathrm{~T}_{\mathrm{A}} ; 40 \mathrm{~T}_{\mathrm{B}} ; 25 \mathrm{~T}_{\mathrm{C}}$; and $37 \mathrm{~T}_{\mathrm{D}}$. Their single tree biomasses and nutrient contents were examined. The outcomes of the study are useful in determining the optimal biomass potential of mixed stands with European beech, oak, sycamore and ash. In forest stands with homogeneous tree species and age distributions the biomass and nutrient quantities could be properly estimated with sufficient accuracy using stand parameters such as mean basal tree area. Nevertheless, in mixed broad-leaf stands, the same estimation was not possible and further analyses are needed.

In the context of sustainability, addressing the environmental, economic and social aspects, is essential for successful 
transformation and must be considered for all value chains within bio-economies. One building block of a bio-economy could be plastic based on renewable resources. Plastics play important roles in society with application in numerous areas of our daily life, from packaging for food, medical and communication technology to technical applications like automobiles. Today, most of these plastics are produced from fossil-carbon-based resources. Against the background of climate change and finite fossil resources, bio-based plastics have been in research focus during the past few decades. In this regard, Spierling et al. (2018) contributed to this field and provided an overview on the sustainability assessment of bio-based plastics, by summarising the currently common assessment practices and related issues, and by highlighting the methodology gaps. Based on the reviewed studies, they developed an approach on how the sustainability performance of bio-based plastics could be calculated, taking the example of the environmental impact category "Global Warming Potential” (GWP).

In their study, the authors documented that, to identify the roles bio-based plastics could potentially have in a bio-economy, it is important to determine the sustainability of bio-based plastics on a global scale. This could serve as a basis to guide future technological developments of bio-based plastics to promising pathways. As part of the environmental sustainability, the GWP was calculated by the authors. They found that bio-based plastics could save 241 to 316 Mio. t. $\mathrm{CO}_{2}$-eq. per year by substituting $65.8 \%$ of all conventional plastics. In performing the review, some limitations were acknowledged by the authors, mainly due to differences in the methods, indicators and results. So, the authors recommended that further research on an improvement and harmonisation of methodology as well as on provision of sustainability information on biobased plastics should be performed, to be able to properly evaluate the real overall potential of bio-based plastics in all of its facets.

The research performed by González-García et al. (2018) was focussed upon the environmental impact assessment of pectinderived oligosaccharides (POS) from sugar beet pulp (SBP). LCA was applied with a cradle-to-gate approach. Two scenarios were considered at a pilot scale: Scenario 1, on conventional autohydrolysis at high temperature; and Scenario 2, on enzymatic hydrolysis. The FU was defined as the valorisation of $100 \mathrm{~kg}$ of dry SBP at the factory gate, provided by a local pulp factory. A "zero burdens" approach was considered to produce SBP, because it was managed as a waste stream from sugar factories. Thus, environmental burdens derived from sugar processing were totally allocated to sugar, the main product. Primary data were used with regard to the foreground system such as electricity consumption as well as the use of chemicals, enzymes and water were average data of the pilot plant (primary data). The characterisation factors reported by the CML 2001 method v2.05 were used for this research. The results were found to be highly dependent upon the production yield of POS and the valorisation strategy considered. The POS yield of the autohydrolysis approach was 20\% higher than the enzymatic one. Scenario 1 produced the worst results when the FU chosen was based upon the amount of valorised material ( $100 \mathrm{~kg}$ of oven-dried SBP). Results changed drastically when a FU was based upon the economic revenue ( 1 euro) was used. The authors concluded that attention should be paid upon the selection of the FU, because it affects the results and the latter affects, decision making strategies.

Finally, some authors investigated utilisation of bio-materials in buildings: among them, Maalouf et al. (2018) who dealt with ecofriendly construction materials (i.e. hemp-concrete; and Recycled Polyethylene Terephthalate (R-PET)) to build facades for office facilities in Italy and France.

They performed an energy performance analysis for each façade, considering several scenarios. Additionally, the Carbon Footprint (CF) was assessed considering both the estimated energy demands and the life-cycle emission factors associated with the energy mix of the countries where the façades were located. The main findings of the study were that the R-PET façade was the most energy efficient and effective performing solution, thus the conclusion, where doable, recycled materials can be used as valid alternatives to natural and conventional materials for construction of green buildings.

\subsection{Theme 2: agriculture}

There is an increasing demand for sustainable agricultural production as part of the transition towards globally sustainable bio-economies. As documented by results of papers selected for inclusion in this bio-economy-related VSI, LCA appears as an ideal tool because of its holistic approach.

Fiore et al. (2018a) assessed different management options in three apricot varieties (Prunus armeniaca L.), and peach varieties (Prunus persica (L.) Batsch) in orchards in Southern Italy through life cycle assessment (LCA). The LCA included all the phases of the orchard (establishment, mature phase and removal), using sitespecific data. The FU adopted was the orchard surface (1 ha) and the GWP was calculated including soil emissions. The study documented that implementation of strategies for sustainability enhancement resulted in a $1 \%-17 \% \mathrm{GWP}_{100}$ reduction. The average mitigation potential for sustainable practices was $-2.7 \mathrm{t} \mathrm{CO}_{2}$ eq. $\mathrm{ha}^{-1} \mathrm{y}^{-1}$. Fertiliser application was the most critical farming operation. In this regard, the authors suggested that policies designed to increase the availability of compost facilities close to orchard producing areas could contribute to increase the overall sustainability of fruit production and further reduce the GWP of production of the fruit.

On a related approach, Simha et al. (2018) considered human urine as a wastewater stream with a potential to be a rich nutrient source. They demonstrated a simple approach to selectively strip urea from human urine in a continuously operated column packed with activated carbon, prepared from agricultural wastes (coconut shells) available around their living location. The authors found that the lessons learned about beneficial results of usage of urine could be used in many other regions, but that in this case the available waste resources should be screened to ensure that the proper technologies are used. In this way, this study succeeded in providing interesting insights to design and implement basic technological approaches that make it possible to use human urine as a resource for the bio-economy.

Keshavarz Afshar et al. (2018) evaluated ammonia volatilisation from cultivated land by applying two nitrogen-based fertilisers and their interactions with tillage system (conventional tillage and no tillage) in arable soils. The, agronomic efficiency of the nitrogen fertilisers was assessed by measuring yield and Nitrogen Use Efficiency (NUE) of camelina (Camelina sativa). The results showed that by replacing urea with super urea no differences in ammonia volatilisation were recorded and that the interaction between $\mathrm{N}$ fertilisers and tillage systems is not appreciable. In addition, urease inhibitor in super urea delayed initiation of ammonia volatilisation after broadcasting fertiliser application. It enables reduction of cumulative ammonia emissions (compared to urea) only if the fertiliser was incorporated into the soil profile within a few days following the application either by a rainfall event or by mechanical incorporation.

Lopes et al. (2018b) analysed the environmental impacts of irrigated cropping systems in the Brazilian semi-arid region (State of Bahia). By implementing various cleaner production options 
(such as adoption of soil analysis for fertiliser recommendation or irrigation based on water balance), the environmental impacts of irrigated carrot production could be reduced by $16-69 \%$. Fertiliser applications and related emissions were the main contributors to the environmental impacts. The costs could also be reduced by the cleaner production options. The authors concluded that the complementary usage of cleaner production and LCA provided valuable support for more sustainable production.

Tricase et al. (2018) investigated barley cultivation from an environmental perspective, by performing a comparative LCA of organic vs. conventional farming, to identify and quantify the most favourable options. Two alternative FUs were considered: one ha of land involved in cultivation of barley to seek environmental sustainability; and one kg of dry matter of grains of barley to document the productive efficiency. The topic was addressed considering the lack of comprehensive comparisons between organic and conventional management of barley production systems, which involve specific methodological assumptions (Tricase et al., 2018). Based upon endpoint results, when the FU is 1 ha of cultivated field, organic cultivation generates environmental lower impacts than the conventional ones ( $2.33 \mathrm{pt}$ vs. the $2.55 \mathrm{pt})$. The results changed drastically when using a mass-based FU: organic barley showed, poorer environmental performance compared to conventional farming: $3.103 \mathrm{E}-04 \mathrm{pt}$ vs. $2.396 \mathrm{E}-04 \mathrm{pt}$.

Results should be attributed mainly to the lower grossproduction yield of the organic farming ( $7.50 \mathrm{t} / \mathrm{ha}^{*} \mathrm{y}$ ) compared to the conventional one $\left(10.50 \mathrm{t} / \mathrm{ha} \mathrm{H}^{\mathrm{y}}\right)$. The result of this is that the overall environmental impact associated with the organic farming is amplified compared to the conventional farming, when modelling is done using a mass-based FU.

In light of this, it could be concluded that organic barley cultivation is more environmentally sustainable (but not efficient in production), vice versa conventional barley cultivation is more efficient in production (but is not environmentally sustainable).

Considering the large quantities of freshwater consumed and polluted in agriculture, Lovarelli et al. (2018) developed a Pollution Water Indicator (PWI) for assessment of the intensity of water pollution, by identifying the effect of the main polluting substances from maize cultivation. As is known, Water Footprint (WF) is based upon estimation of the pollutants that required the highest water dilution volume. This new tool goes beyond this, as it estimates the effect of other on-field applied substances, like nitrogen, phosphorous and pesticides, that, however, cannot be neglected, especially when huge amounts of organic fertilisers are administered.

For PWI estimation, both grey water and the water-related environmental impact categories like freshwater eutrophication, marine eutrophication and freshwater ecotoxicity were accounted by the authors and evaluated through LCA.

In this context, the authors proposed a framework to assess both the environmental impact and the consumption of freshwater. To that end, different techniques for the spreading of organic fertilisers (i.e. pig slurry) and different irrigation technologies with variable technical efficiency were compared for WFA quantification of maize grain production in Northern Italy.

Some of the field operations for maize grain cultivation, which considerably affect freshwater degradation and consumption, were assessed by the authors as alternatives to the Baseline Practice (BP) providing surface slurry spreading incorporated after $>72 \mathrm{~h}$; those alternatives are: 1 ) fast incorporation, of pig slurry within $2 \mathrm{~h}$ after spreading; 2) direct injection of pig slurry in the soil in 7-10 cm deep furrows; 3 ) straw collection, in which the difference from BP arises from the collection and baling of straw, involving a higher nutrient removal and a consequent higher organic fertiliser mass applied; 4) administration of digestate (instead of pig slurry) from a biogas plant fed with maize silage and pig slurry is used; and 5) administration of urea and triple superphosphate instead of pig slurry.

With regard to spreading the pig slurry, according to the authors PWI resulted better when nutrients leaching is reduced, while it was worse with fast soil incorporation and direct soil injection of organic fertilisers that, by reducing ammonia volatilisation, involve higher nitrate losses.

Concerning irrigation, sprinkler and drip irrigation are highly recommended because they make it possible to increase efficiency of irrigation water usage, with blue water between $-33 \%$ and $-60 \%$ of total WFA with drip instead of surface irrigation.

Gallo et al. (2018) is aimed at the study of the Kyoto Protocol repercussions on the agricultural and forestry sector. The emission levels of Greenhouse gases are greatly changed from a geographical point of view over the years after that protocol.

In this regard, the authors documented that the introduction of tradable permits in the market, along with the participation in Kyoto Protocol based policies has had great influence on the emissions of GHGs in the agricultural and forestry sector and on the importance of adopting solutions for their reduction. With regard to this point, the authors highlighted that the design and timing of policy interventions is crucial for reducing innovation barriers and improving production efficiency. In addition to this, the proper use of available databases linked to the identification and application of tools by decision makers for grooming emissions were documented by the authors as one of the main drivers for improving the efficient use of resources and for global warming reduction.

In another study, Shi et al. (2018) investigated consumer perceptions of the climate impact related to food products. Based on online experiments, they showed that consumers can assess the climate impact of food products in relation to type of food, country of origin, season and transportation, while they were less knowledgeable of the extent to which the food products differed in regard to their climate impacts. Shi and colleagues concluded that communication about the impact of food products is key to enable consumers to better assess the climate impact of food products and to enable them to make climate-friendly food choices.

Ferrari et al. (2018) assessed the environmental impacts of Lambrusco red wine production. In particular, the cultivation, management and disposal of vineyard wastes were evaluated considering different soil characteristics the vine spacing. The selected FU was the productivity per hectare of wine grapes. Primary data related to cultivation, management and disposal of three planting patterns were directly collected from the wine producers while secondary data were used for materials, chemicals, electricity, transport, infrastructure and machineries as well as for the environmental emissions arising from the application of fertilisers and pesticides. The IMPACT 2002 + method, covering 15 midpoint impact categories, was used to perform the life cycle impact assessment. In this study, the grape sugar content, that is related to the wine quality, was considered as a coproduct. Results showed that, considering the grape quality, the damage was lower for the $3 \times 0.8$ planting pattern even if the vineyard lifetime is longer. In addition to this, higher damage was found by the authors to be attributed to direct emissions of fertilisers and pesticides and to agricultural land occupation.

In another study, Merli et al. (2018) examined different programmes to assess the sustainability of wine production. They identified the main environmental impacts of wine production via LCA assessments. Based on a set of defined criteria, 20 programmes for the assessment of sustainability in Europe and America were screened. Three programmes were selected for a detailed analysis and comparison, each having its strengths and weaknesses. The analyses revealed that the great heterogeneity and variety of tools, indicators and certifications could be confusing for companies and 
consumers. The authors concluded that joint efforts of the different sustainability programmes could result in sustainability improvements. However, care must be taken that the assessment is objective, transparent and verifiable and that local specificities are taken into consideration.

Polimeni et al. (2018) stated that understanding consumer motivations for buying sustainable agricultural goods at farmer's markets is an important activity because it can increase sales of sustainable agricultural products and improve economic development. In turn, the increase in sustainable agricultural production is beneficial for the environment, in that land and water contamination will be reduced following the decreased usage of toxic pollutants that are typical conventional agriculture practices. In their paper, Polimeni et al. (2018) investigated the factors that influenced consumers' choices in purchasing sustainably produced agricultural products in Romania. The authors focussed attention upon farmer's markets because: they are important for local economic development, especially in rural areas; they provide food to urban dwellers; and they are a source of inexpensive, quality products for the elderly and the poor. In addition, according to the authors, consumers at farmer's markets are older people who are interested in aspects like healthiness, safety, sustainability and economic convenience of foods. Results from this study suggested that consumers are interested in knowing about production practices used by the producers of the food that they purchase and are also interested in the interconnections among environment, community building, and their personal health. Furthermore, the economic value, wealth, and educational level are important factors for consumers to choose sustainable products at farmer's markets. Agreeing with the authors, this paper is relevant because, based upon their requirements, sellers can even more specifically target consumers, thereby resulting in increased economic development and environmental sustainability in agriculture.

In line with the importance of consumers in the management and improvement of agriculture and food production, Valente and Chaves (2018) explored consumer attitudes towards genetically modified food products. They adopted an 'economic contingent valuation,' approach to highlight the relevance of information provision. The authors found that provision of more information is needed for consumers to make more informed decisions.

Varela-Candamio et al. (2018) investigated participation of rural women in the agricultural system of functional foods, through a better understanding of their multiple roles in the supply and demand of functional foods as competitive advantage. According to the authors, the objective of the paper was twofold: estimating the farming Technical Efficiency (TE), by evaluating the factors affecting farm efficiency for each type of farming in Spain; and proposing a multi-layered model to evaluate whether rural women have competitive advantage as local entrepreneurs of businesses based on functional foods due to their positioning in the processes of generation-production-consumption of these foods. The main objective of the authors was to analyse the triangular relationships among efficiency, environmental friendliness and subsidies in Spain, as a representative Mediterranean member of the EU. The findings revealed that public subsidies have negative impacts on TE in the Spanish agricultural sector, both on average and by type of farming. This has implications on the issue, about whether the farm income support of the EU Common Agricultural Policy (CAP) is suitable to achieve its goal to increase farmer' competitiveness by improving their efficiency. However, based upon findings from their research, the authors recommended Direct Payments (DP) to be incentives for environmentally friendly behaviour by farmers to improve their productive efficiency. The authors encouraged participation of society from a Bioeconomic approach, through new commercial uses of farming land that increase healthy consumption and the viability of green business models (VarelaCandamio et al., 2018).

As one way to search for innovation and improvement in agriculture, Senyolo et al. (2018) identified available climate-smart agricultural technological innovations in South Africa and explored their characteristics and context of usage via usage of an exploratory research approach. Through their study, the authors documented that Conservation Agriculture, Rainwater Harvesting and Seed Varieties that are Drought Tolerant and Early Maturing may be the most suited technologies for climate-smart agriculture in South Africa, particularly for smallholder farmers. However, high initial investment costs, additional labour requirements and management intensity associated with conservation agriculture and rainwater harvesting were found to pose potential problems within the South African context. By contrast, Drought Tolerant and Early Maturing Seed Varieties were noted as less costly and less management intensive, and they create better prospects for adoption.

LCA practitioners are often confronted with the choice of the most suitable databases or datasets for their study, but systematic analyses and comparisons of LCI databases are rare in the literature. Corrado et al. (2018) assessed twelve datasets for arable crops in France originating from the databases Agrifootprint, Ecoinvent and Agribalyse. Large differences were detected in the definition of system boundaries and modelling of agricultural practices, characteristics of inventory data, agricultural operations, fertiliser application and fate, plant protection products application and fate, heavy metals inputs to the agricultural system and fate, irrigation assumptions, land use and transformation. These differences strongly influenced the impact assessment results. Recommendations for LCA practitioners and database developers were proposed by the authors.

In addition to issues related to databases, an important aspect to be considered when performing LCAs in agriculture is about which tool to use. According to Goglio et al. (2018a), many tools have been developed in recent years for application of LCA in the agricultural field but are not publicly available and are not open-source and have limited scopes. To solve this and other problems, the authors (Goglio et al., 2018a) implemented a new, adaptable open-source, transparent tool, named "Crop.LCA" for performing LCAs of cropping systems. Through application to a set of cropping systems, Goglio et al. (2018a) highlighted that Crop. LCA effectively captures characteristics and variability, of cropping systems, as well as the interactions of soil with climate and crop management. The tool has the advantage of accounting for several substances, thereby, enabling the researcher to assess individual crops or cropping systems over several years. Therefore, it is considered to be a step forward in increasing LCA accuracy and suitability for reliable assessment of those systems in a bio-economy context.

Goglio et al. (2018b) made a comparison of different methods to quantify greenhouse gas emissions of cropping systems. They compared several methods of estimating $\mathrm{CO}_{2}$ and $\mathrm{N}_{2} \mathrm{O}$ emissions for an LCA of different cropping systems. They evaluated the relative contributions of soil GHG emissions to the overall GWP using results from a field experiment located in Canada. The following methods were considered: measurements; Tier I and Tier II IPCC, which is a simple carbon model combined with IPCC Tier II methodology for soil $\mathrm{N}_{2} \mathrm{O}$ emissions, and the DeNitrificationDeComposition (DNDC) agroecosystem model. The authors found that estimates from a properly calibrated agroecosystem model or a simple model combined with IPCC Tier II methodology can be used in place of detailed observations to account for GWP in LCA of cropping systems.

Rota et al. (2018) developed a tool for assessing collaboration in the food and fibre sector. Based on the case of the Egyptian organic and fair-trade cotton supply chain, from an explanatory factor 
analysis they defined six distinct factors to indicate how to implement effective collaborative strategies. Those factors were assigned to three different dimensions of collaboration between company owners/managers and farmers, as shown in Fig. 2.

Freire (2018) developed a multilevel framework to assess the implementation of eco-innovation processes in industrial sectors and companies. Based on the case of the Brazilian petrochemical sector, he identified the willingness to engage in eco-innovation and its antecedents. He concluded that a host of stakeholders and partnerships are key in developing the conditions and stimuli for the implementation of technical and non-technical changes at the company and sectoral levels.

Finally, in line with those two papers, Aiello et al. (2018) showed how a decision-support system (DSS) based on the information gathered by a sensor network, can support small farmers in greenhouse operations and management. The reported results suggest that introducing such systems into the production chains, could help to improve the usage of natural resources, especially when they are coupled with prediction models.

\subsection{Theme 3: forestry}

Forest-based biomass value chains are an important pillar of the bio-economy. Several contributions to this VSI were presented in the conference "Towards a Sustainable Bio-economy - Innovative Methods and Solutions for the Agriculture and Forest Sectors", which was organised in Barcelona, Spain in October 2015. The building and construction industry is a massive source of global $\mathrm{CO}_{2}$ emissions and there is considerable need to mitigate emissions from this sector. Modern wood construction methods could offer sustainability benefits while supporting the bio-economy transition.

(Hurmekoski et al., 2018). Industries have set ambitious targets for 2030 related to green buildings which, in the wood-frame construction field, means: tripling the market share of wood construction; doubling the value added of the woodworking industries; and finding solutions for reduction of the environmental impacts of construction by $30 \%$. Using a Delphi back-casting method, Hurmekoski et al. (2018) found that (1) a gradual increase of competition and the resulting increased credibility among the construction stakeholders as well as (2) introducing more direct policy support measures downstream in the construction value chain, constitute important pathways to reach these targets in wood-frame multi-storey construction in Finland.

Wood has a long-standing history as an industrial material and fuel: therefore, LCAs are needed to create sets of inventory data in order to quantitatively assess and reduce those environmental impacts mentioned by Hurmekoski et al. (2018). In this context, Nakano et al. (2018) estimated cradle-to-gate GHG emissions for round wood production of the following four tree-species, in that they provide more than $80 \%$ of total round wood production in Japan: Japanese cedar (Cryptomeria japonica), hinoki cypress (Chamaecyparis obtusa), Japanese larch (Larix kaempferi), and Sakhalin fir (Abies sachalinensis). The authors found that $41-46 \%$ of the total value chain emissions were related to final fellings. A substantial contribution to GHG emissions came from worker's commuting, which is often neglected in similar assessments. Regional data varied considerably because of substantial differences in the degree of mechanisation in the felling technics.

Based upon findings from their study, the authors recommend to improve: the energy efficiency of the felling process; and the labour productivity to reduce, in turn, the GHG emissions resulting from commuting workers.

Three studies addressed the cascade use of wood, which is subject to considerable political discussions. Thonemann and Schumann (2018) conducted a literature review related to impacts of wood cascading and found that most studies used LCA methods to quantify environmental impacts, whereas an assessment of resource efficiency was largely missing from the published assessments.

Bais-Moleman et al. (2018) addressed this shortcoming in their study on cascading usage of woody biomass, which also analysed the overall wood flow efficiency in the European Union's forest and bio-economy sectors. Using a scenario and life cycle approach, they compared a reference with two alternative scenarios and found that through cascading usage, the wood use efficiency ratio (cascade factor) in the European wood sector could be increased between $23 \%$ and $31 \%$ through waste wood and paper recycling, by using currently prevailing practices and maximum technical potentials, respectively. The increased wood usage efficiency was, however, counter effected by reduced short-term savings in the energy sector due to the delayed availability of waste wood and waste paper fibres. The cascading usage of woody biomass can thus, have conflicting long-term impacts on wood resource efficiency and short-term impacts related to energy use and GHG emissions reductions - trade-offs which, require special attention,

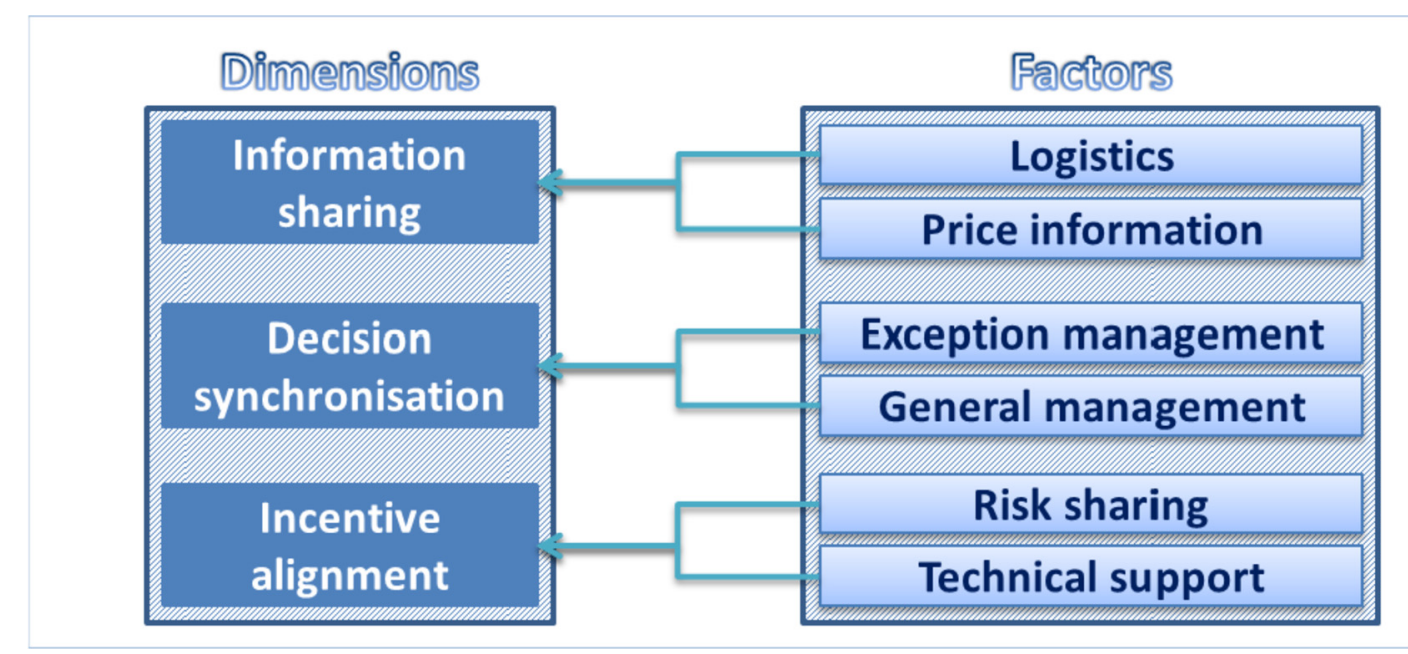

Fig. 2. The figure shows the distribution of the six factors in the three collaboration dimensions identified. Source: personal elaboration from Rota et al. (2018). 
considering their net effects on short-term (2020-2030) renewable energy targets.

Brunet-Navarro et al. (2018) performed a modelling study to quantify the carbon storage impacts of alternative wood product utilisation strategies with different modelling approaches. They found that some wood product models significantly overestimate carbon stock in wood products due to the use of infinite recycling loops. They quantified the effects of replacing such loops with cascade chains in a case study for the German wood sector and found that the estimated carbon storage declined approximately by $15 \%$ by using the cascade chains. Their modelling study suggested that strategies to promote the development of new product designs and material technologies to enhance cascading may have considerable impact on carbon stock in the wood product sector and thus on climate change mitigation.

Ramcilovic-Suominen and Pülzl (2018) reviewed different definitions of sustainability and sustainable development and analysed how current bio-economy policies relate to these concepts. They argued that the current European Union bio-economy policy leans strongly towards weak sustainability (ie. a sustainability understanding in which different types of capital such as natural or social capital can substitute for each other) and a utilitarian and instrumental approach to sustainable development where economic concerns prevail over the environmental and social dimensions. They call for a broader definition of sustainability within the bio-economy policy that strengthens environmental and social concerns and safeguards.

Blumberga et al. (2018) introduced a system dynamic model to understand the interdependencies among the different aspects of a bio-economy (land use, production and consumption of raw material, research and development, amongst others), and sustainability. Through the development of this model the authors sought to answer the following research questions: How can the current use of bioresources be extended into new value chains for generating higher value added, and what are the resources (natural, human, financial) required? They validated their model by applying to the Latvian forestry sector, and particularly by considering birch wood as the case study raw material. The application of the model allowed the authors to identify the following three factors as critical for bio-technology development: bio-resources, production capacities which allow processing the bio-resources into products and the possibility to add value to these resources.

Another governance-related study analysed how the transition towards a bio-economy evolved in Finland, with a focus upon citizen participation (Mustalahti, 2018). The author found that interactive collaborative approaches are needed to empower various institutions and people to meet and debate about bio-economy developments. Responsive governance was found to be important in ensuring that many change-agents contributed to the relevant processes of the bio-economy transition. Citizens' values, interests, know-how and environmental entitlements were found to be key drivers of change.

On governance related issues, Jürges and Hansjürgens (2018) analysed an important but underdeveloped research field, which is the soil governance, particularly in the context of the transition towards a sustainable bio-economy. Among several interesting aspects, the authors found that sustainable governance in this field should be based on effectiveness, efficiency and legitimacy, and must also address unintended spill-over effects and trade-offs in space and time. Another interesting conclusion pertained the improvement of understanding on-farm decision-making processes as a cornerstone to improve the knowledge basis for the design of soil governance instruments. This conclusion supported the thesis of a need of holistic approaches supported with information from multiple levels of aggregation (local, regional, national, international) to understand and to implement the bioeconomy system.

Social factors were the focus of developing a social life cycle assessment tool that was applied to wood-based production systems (Siebert et al., 2018c). The authors developed a set of social indices and related indicators and tested them empirically for wood-based production value chains in Germany. The extended social LCA framework helped practitioners to develop a comprehensive overview of social hotspots and opportunities for regional producers and therefore, provided a regional perspective in the monitoring of the social implications of wood-based products.

\subsection{Theme 4: production and packaging of foods and feeds}

In recent decades, the supply for animal products has been increasing due to growing food needs and demands (Fiore et al., 2018b). Livestock production, particularly the beef supply chain, is regarded as the major contributor to GHG emissions, as well as to land degradation and deforestation (Bragaglio et al., 2018). The activities of the livestock sector have impacts upon climate change with emission of methane (44\%), carbon dioxide (27\%), and nitrous oxide (29\%).

In this context, Bragaglio et al. (2018) performed a comparative LCA of four beef production systems. According to the authors, they are the most common ones, which rely upon bull production in Italy and include local and specialised breeds initially kept on pasture and then finished in confinement, imported specialised breeds finished in confinement, and specialised breeds permanently kept in confinement. The authors documented that intensive beef production performs better than open pasturage in terms of GWP and land occupation, and worse in terms of acidification and eutrophication potential.

Challis et al. (2018) focussed upon the dairy industry and assessed process control behaviour regarding energy efficiency based on an ethnographic study of two types of dairy processing sites in the UK. They concluded that currently, dairy production processes are seldom controlled to minimise energy consumption, while there is a high potential for process control to achieve energy usage reductions. As a result of this study, dairy processing managers were recommended to gather and use energy consumption data and to communicate the need to reduce energy consumption to their process operators to take advantage of the energy saving potentials by systematically improving process controls.

Animal feeding is crucial in terms of both production efficiency and environmental impacts for the livestock sector and farmer choices about home-grown feed can have great influence on environmental impacts of milk and meat production (Zucali et al., 2018). Fiore et al. (2018b) documented that production of animal feed and the enteric fermentation of ruminants are the two major sources of methane emissions, by contributing $45 \%$ and $39 \%$ of the total emissions, respectively. On a product basis, milk and beef are responsible for most of the emissions and environmental impacts associated with livestock breeding, including production of the feeds (Fiore et al., 2018b).

Zucali et al. (2018) investigated the field of home-grown fodder crops (i.e. maize for silage, Italian ryegrass, alfalfa, permanent grass and winter cereals for silage) in Northern Italy by analysing alternative cropping system scenarios (HAY, SILAGE, and PROTEIN) at the dairy farm level to find the most environmentally favourable option.

The authors found that: the HAY scenario was when the entire farm land is dedicated to permanent crops (grass and alfalfa) for hay production; in the SILAGE scenario, most of the farm land is used for cultivation of crops preserved as silage; and the PROTEIN scenario was considered when the cropping system was for 
maximising production of protein from home-grown feed. According to the authors, the study explored two important aspects: the first was about estimating the environmental impact for fodder production considering the Net Energy for lactation and the digestible protein in the small intestine as FUs. Based upon the research results, the authors concluded that alfalfa silage showed the best performances in terms of impact categories analysed, especially when the impacts were expressed per unit of net energy for lactation or digestible protein in the intestine. The second aspect researched was the analysis of alternative cropping system scenarios at dairy farm level, which showed that alfalfa and grass haybased cropping systems (HAY scenario) had the lowest selfsufficiency on a dry matter base, and the highest values for all impact categories per $\mathrm{kg}$ of fat- and protein-corrected milk. By contrast, the PROTEIN scenario had the highest feed self-sufficiency both in terms of dry matter and crude protein content. The authors documented this scenario to be the best in a global perspective, as it performed best in terms of acidification and eutrophication potentials, as well as in terms of non-renewable fossil energy use per $\mathrm{kg}$ of fat- and protein-corrected milk. It was also characterised by a reasonable value in terms of GWP, which made it more competitive compared to the other scenarios considered (Zucali et al., 2018).

Fiore et al. (2018b) addressed the link between cattle emissions and economic performance in response to the environmental, economic and societal challenges, that need to be faced to transition to equitable, sustainable, post fossil-carbon societies. In their study, the authors classified cattle farm emissions with respect to the economic performance variables of the Italian cattle farming sector and classified segments of farms and firms in clusters. Based upon findings from the study, GHG emissions increased with the increase of the production amount, yet only if the firm handling the processes is not efficient. The research findings showed, that virtuous cattle farms practice regimented and planned resource management, which can result in reduced GHG emissions.

Noya et al. (2018) performed LCA analyses to document the environmental criticalities associated with cultivation of three cereal crops typically used for animal feed purposes - barley, rye and sorghum, in the Lombardy region, the most productive crop and livestock area in Northern Italy. Based upon results from the research, varieties like Reni (for barley) and Dank Nowe (for rye) were documented to be those with the lowest environmental impacts for barley and rye varieties. In addition to this, single cropping of sorghum had lower impacts than double cropping. Through their study, the authors found the impact hotspots to be: field emissions; agricultural activities; and agrochemical (fertilisers and herbicides) production regardless of the cropping system considered. Moreover, among the cereals studies, rye was found to be the best environmental alternative. In regard to methodological choices, the authors highlighted that the ranking of systems according to their impacts was not affected by the use of either land-based or economic functional units.

Ahmed et al. (2018) highlighted potentials and challenges associated with cultivation of freshwater prawns (Macrobrachium rosenbergii de Man) in Southwest Bangladesh. Several concerns were identified related to environmental impacts, animal welfare, socioeconomic aspects and consumer protection. The authors documented that overcoming those concerns and converting an extra $10 \%$ of the prawn farming areas to organic farming could provide the Bangladesh economy with an extra income of $\$ 8.19$ million annually. In this context, Ahmed et al. (2018) developed a set of recommendations to establish organic prawn farming: i) increase farmer awareness; ii) increase institutional support and strong collaborations among stakeholders, iii) particular attention must be given to hatchery operations, feed formulation, and growout operations to correspond with organic aquaculture standards; iv) organic certification for export markets must be done; v) empirical research to develop organic prawn farming to meet social, economic, and ecological challenges must be done.

Egelyng et al. (2018) addressed the interconnections between bio-economy and the food industry, by seeking to answer research questions about concrete innovations designed to create bioeconomic transition options in Norway. They found ways, from a transdisciplinary investigation of Norwegian food industry cases involving processing of fish, meat, fruit, and vegetable co-streams to capture and to increase use and value of residues from processing. The results showed that while the objectives of avoiding food losses and transforming co-streams to new products of higher value characterised the poultry industry case and part of the 'blue' sector, challenges remained particularly in the 'whitefish' area where - also at the global level - a high share of fish resources are wasted or are not fully utilised. The authors found that strategic cases of innovations enabling alternative uses of co-streams enabled their cascading and valorisation and documented why an upcycling potential exists, as well. The authors documented that the bioeconomic transition towards sustainability is possible only when transdisciplinary research and innovative options are feasible and interlinked.

\subsection{Theme 5: innovation systems - policies and tools}

As highlighted in the previous sections, transitioning towards a bio-economy is necessary to support a steady provision of resources, thereby they provide alternatives to usual economic and abiotic resources. However, to ensure responsible access to and sustainable usage of those resources, it is needed to duly account for that usage along supply chains, as well as to define a robust and comprehensive impact assessment model. In this regard, by scanning through the literature of the sector, it was learned that naturally occurring biotic resources have gained little attention in impact assessment methods, like LCA. Crenna et al. (2018) contributed to fill this gap by research with the objective to evaluate the feasibility of including biotic resources in LCAs of products and supply chains. The authors achieved their objective to improve the inventory of naturally occurring biotic resources, by identifying and listing the most commercially valuable species, which could be used as elementary flows in LCA inventories. In this regard, additional research was recommended to overcome issues related to heterogeneity of indicators and to address their feasibility in describing the impacts on resource availability in the LCA context. The authors proposed the use of renewability time to calculate characterisation factors for biotic resources and their depletion. The authors concluded that their findings could serve as a coherent framework to improve the modelling of biotic resources in LCAs, thus they took a step forward to make it possible for the methodology to comprehensively account for crucial elements affecting environmental sustainability of products.

In an approach similar to that used by Crenna et al. (2018), Karabulut et al. (2018) proposed a synthesis matrix system to describe the complex and closely bound relationships between natural resource usage for food, energy and ecosystems, along the lines of the concept of ecosystem-water-food-land-energy nexus. The author's main objective of the matrix was to integrate quantitative and qualitative aspects which, have often been neglected in traditional approaches to impact assessment. According to the authors, the matrix is suitable for being defined at different scales and was designed to include impacts to and nexus with climate change. In addition to this, as the matrix was designed to support and favour holistic assessments of supply chains, the authors proposed integrating it with LCA although, in their opinion, further development work is still required. 
Based upon their findings, the matrix developed revealed that there are predominantly negative impacts due to sectoral uses of resources on the provision of ecosystem services. In agreement with the authors, this editorial team underscores that this issue requires much more focus upon the reliable and efficient usage and sustainable management of resources and the related environmental, economic and social impacts, while reducing the trade-offs between the competing demands.

Sustainable development and poverty eradication are strictly inter-connected according to Cheng et al. (2018); they are common missions of humanity and are top priorities of the Chinese government. Nevertheless, the poverty of reservoir immigrants is usually interwoven with eco-environmental and geo-disaster factors, making poverty alleviation the most challenging task in rural China (Cheng et al., 2018).

Cheng et al. (2018) investigated this field of research and used a System Dynamics Model (SDM) to: explore interactive mechanisms of eco-environment, geo-disasters and immigrant poverty in order to enable policy makers to understand the impacts of different investment strategies on the key variables and the sustainable development of China's Poverty-stricken Reservoir Regions (CPRR).

Through their study, Cheng et al. (2018) found that: China's Poverty-stricken Reservoir Regions are highly likely to achieve the poverty reduction goals by 2020 by taking the coordinated strategy and by paying more attention to disaster management and to a coordinated development scenario which, could help to systematically reduce poverty, sewage discharge, disease incidence, geodisasters, soil erosion, and increase the areas of forest cover and agricultural land. According to Cheng et al. (2018), the results could help to generate recommendations for policy makers and could provide a method to implement best practices for the sustainable development of CPRR.

Koukios et al. (2018) prepared a policy-oriented opinion paper, under the form of a Manifesto that was built upon ten theses that are the basis of their assessment. The theses were analysed in the context of the experiences of six European countries, and with these results the authors proposed recommendations that could strengthen the implementation of the bio-economy. Among other recommendations, the authors suggested fostering strong national innovation-oriented research systems designed to take into consideration the current transition processes such as the information, bio and nano-waves of change; to take into account the soft aspects of technology and to foster appropriate multi-policy environments; and to foster the incorporation of an international dimensions into the research actions, while enhancing flexibility in optimal regional specialisation to the most appropriate mix of bioeconomic solutions.

Aquilani et al. (2018) performed research to focus upon innovation, as essential for development of sustainable bio-economies, and on the need for new business models and managerial approaches to be applied at the firm level. According to the authors, innovation and sustainability are the natural touch points between bio-economy and business management and should be the core issues for implementation of new firm theories, models and approaches.

In this context, Aquilani et al. (2018) proposed a new framework designed to explicitly integrate the key features of the "Sustainability Oriented Theory of the Firm" (SOTF) into a value co-creation model. The objective of the research was to integrate the core dimensions and principles of Corporate Sustainability (CS) into an updated firm approach focussed upon innovation, thereby, helping to highlight reliable and sustainable ways for firms to contribute to bio-economies. For this purpose, the authors considered the four dimensions of CS, namely those related to society, economy, environment, and time. In addition, by building upon the relevant literature, the authors considered the key principles upon which the SOTF approach is based. By combining those dimensions and principles with the value co-creation approach, the authors documented that CS can be achieved through an up-to-date strategy perspective. The latter needs, however, to consider the challenges that firms worldwide are called to face in the current complex scenario.

According to the authors, the main contribution of the paper was to make progress in integrating the SOTF principles and the CS dimensions to develop strategies encompassing both innovation and sustainability related issues as the base for implementation of a bio-economy.

\section{Conclusions}

This VSI achieved the proposed goal of highlighting the importance of academic research upon bio-based concepts, tools, technologies, education and policies to help them to play increasingly central roles in accelerating the transition to equitable, sustainable, post fossil-carbon societies.

From a thematic perspective, several issues were identified as integral results of this VSI. Firstly, that bioenergy is still an important research subject in the international context and particularly in the bio-economy research field. Secondly, that there is increasing interest in the multiple future roles of bio-economy in the agricultural and forestry sectors, particularly for the various alternatives for processing of the material streams associated with the production infrastructures for achieving the greening of the overall sector.

By analysing the different perspectives and approaches presented in the sixty-eight papers of this VSI, it was possible to highlight five major aspects and recommendations:

1. Although the bio-economy is a process that must be addressed in many scales (local, regional, national, international), most of the research in the various fields of the bio-economy were performed via case studies analyses at regional or country levels. Although this is interesting, in that it allows building the bottom-up knowledge foundation for the bio-economy sector, the generalisation of these results is rather difficult. Therefore, the first recommendation for future research is the call for more meta- and sector-wide studies of cross-country/regional interventions, to assess which interventions are likely to be most effective.

2. The research presented, adopted a large variety of methodologies to assess bio-economy systems. Thus, the second recommendation from this VSI highlights the need for harmonisation of methodological approaches adopted to assess the bio-economy. This allows further benchmarking and more accurate comparisons of new and innovative technologies and bio-economy systems;

3. By reviewing studies belonging to this VSI, it is clear that soil and climate conditions, as well as carbon and nitrogen cycles, are highly interconnected dimensions. Their accounting in LCAs needs to be performed accurately, because it was documented to be crucial for modelling of agriculture and forestry systems in relation to climate change impacts (Aylott et al., 2011; Goglio et al., 2015; Paustian et al., 2016). Therefore, the third recommendation is to encourage expanded exploration of the interconnected dimensions, holistically and over the longterm, to more effectively assess sustainability issues of agriculture and forestry systems from a bio-economic perspective.

4. Another aspect that has become clear during the analyses of the papers of this VSI was that most authors addressed their research questions from a single discipline perspective. 
Although, this may seem logical from a research perspective, since bio-economy is relevant to several scientific disciplines, the way of addressing the challenges in this field, as previously mentioned, should be done in a multi-disciplinary way. Therefore, the fourth recommendation that arose from analyses of the articles of this VSI was the call for more interdisciplinary collaboration among technical and social scientists to identify and to address the relevant questions for societal transition to the bio-economy.

5. The fifth and final aspect that evolved during the analyses of the papers of this VSI was the small or negligible involvement of industrial partners and/or of other actors of society in identifying the research questions to be addressed by academics in the bio-economy field. This shows the necessity to change the approach for developing bio-based technologies to foster their implementation in the markets. Until now the technology development process has been performed, largely from a research-driven perspective, often without incorporating the systems-perspective to determine the drivers and the players that can make the technological implementations happen. Therefore, it is essential to change the paradigm from a "technology development pipeline" to an "innovation-driven pipeline" for bio-based technological development. In the latter, the success of technical development ("success" meaning that the implementation of the developed bio-based technologies and hence the finalisation of the "innovation process") is subject to the industrial pull to place the bio-based products or services on the market. Therefore, the fifth recommendation is to foster the exchange and involvement of academics with all actors and stakeholders of the "innovation pipeline" of the bio-economy, including policy- and decision-makers. This will help in identifying not only the governance issues on a national and international level but will also include the relevant market players, which were often neglected in technology assessment studies.

Finally, this VSI issue made it possible for the editors to collect important examples of the multiple greening effects that the bioeconomy has in the sectors considered: for this reason, it is expected that it will help to broaden and deepen the platform for exchanging and enhancing knowledge on the bio-economy.

\section{Acknowledgements}

Dr. Carlo Ingrao would like to thank all the guest editorial board members because, without their supportive commitment and work, this VSI would have never been possible.

Special thanks to Prof. Donald Huisingh (Editor-in-Chief Emeritus of the Journal of Cleaner Production) for his multiple key roles and contributions in the planning, development and handling of this VSI, including in the writing of this document.

In addition to this, the whole guest editorial board would like to thank all the authors for contributing as high-quality manuscripts to this VSI as they have.

Finally, the authors wish to thank the Co-Editor-in-Chief of the Journal of Cleaner Production (Prof. Cecilia Maria Villas Bôas de Almeida) for kindly handling this paper submission and three anonymous reviewers for their invaluable comments on an earlier version of this editorial manuscript.

\section{References}

Abdulrahman, A.O., Huisingh, D., 2018. The role of biomass as a cleaner energy source in Egypt's energy mix. J. Clean. Prod. 172, 3918-3930.

Ahmed, N., Thompson, S., Glaser, M., 2018. Transforming organic prawn farming in
Bangladesh: potentials and challenges. J. Clean. Prod. 172, 3806-3816. Aiello, G., Giovino, I., Vallone, M., Catania, P., Argento, A., 2018. A decision support system based on multisensor data fusion for sustainable greenhouse management. J. Clean. Prod. 172, 4057-4065.

Alemán-Nava, G.S., Gatti, I.A., Parra-Saldivar, R., Dallemand, J.F., Rittmann, B.E., Iqbal, H.M., 2018. Biotechnological revalorization of Tequila waste and byproduct streams for cleaner production-A review from bio-refinery perspective. J. Clean. Prod. 172, 3713-3720.

Alexiades, A., Kendall, A., Winans, K.S., Kaffka, S.R., 2018. Sugar beet ethanol (Beta vulgaris L.): a promising low-carbon pathway for ethanol production in California. J. Clean. Prod. 172, 3907-3917.

Aquilani, B., Silvestri, C., Ioppolo, G., Ruggieri, A., 2018. The challenging transition to bio-economies: towards a new framework integrating corporate sustainability and value co-creation. J. Clean. Prod. 172, 4001-4009.

Aylott, M., Higson, A., Evans, G., Hamer, A., Mortimer, N., 2011. What is the most appropriate LCA method for measuring greenhouse gas emissions from bioenergy? Biofuel. Bioprod. Bioref. 5, 122-124.

Bacenetti, J., Lovarelli, D., Ingrao, C., Tricase, C., Negri, M., Fiala, M., 2015. Assessment of the influence of energy density and feedstock transport distance on the environmental performance of methane from maize silages. Bioresour. Technol. 193, 256-265.

Bais-Moleman, A.L., Sikkema, R., Vis, M., Reumerman, P., Theurl, M.C., Erb, K.-H. 2018. Assessing wood use efficiency and greenhouse gas emissions of wood product cascading in the European Union. J. Clean. Prod. 172, 3942-3954.

Balata, G., Tola, A., 2018. Cost-opportunity analysis of the use of Posidonia oceanica as a source of bio-energy in tourism-oriented territories. The case of Alghero. J. Clean. Prod. 172, 4085-4098.

Bezama, A., 2016. Let us discuss how cascading can help implement the circular economy and the bio-economy strategies. Waste Manag. Res. 34 (7), 593-594.

Bezama, A., 2018. Understanding the systems that characterise the circular economy and the bioeconomy. Waste Manag. Res. 36 (7), 553-554.

Blumberga, A., Bazbauers, G., Davidsen, P.I., Blumberga, D., Gravelsins, A., Prodanuks, T., 2018. System dynamics model of a biotechonomy. J. Clean. Prod. 172, 4018-4032.

Boscaro, D., Pezzuolo, A., Sartori, L., Marinello, F., Mattioli, A., Bolzonella, D. Grigolato, S., 2018. Evaluation of the energy and greenhouse gases impacts of grass harvested on riverbanks for feeding anaerobic digestion plants. J. Clean. Prod. 172, 4099-4109.

Bosman, R., Rotmans, J., 2016. Transition governance towards a bioeconomy: a comparison of Finland and The Netherlands. Sustainability 8 (10), 1017.

Bragaglio, A., Napolitano, F., Pacelli, C., Pirlo, G., Sabia, E., Serrapica, M., Braghieri, A. 2018. Environmental impacts of Italian beef production: a comparison between different systems. J. Clean. Prod. 172, 4033-4043.

Brunet-Navarro, P., Jochheim, H., Kroiher, F., Muys, B., 2018. Effect of cascade use on the carbon balance of the German and European wood sectors. J. Clean. Prod. 170, 137-146.

Cerveira, C.S., Borges, C.P., Kronemberger, F.D.A., 2018. Gas permeation applied to biogas upgrading using cellulose acetate and polydimethylsiloxane membranes. J. Clean. Prod. 187, 830-838.

Challis, C., Tierney, M., Todd, A., Wilson, E., 2018. Human factors in dairy industry process control for energy reduction. J. Clean. Prod. 168, 1319-1334.

Cheng, X., Shuai, C.-M., Wang, J., Li, W.-J., Shuai, J., Liu, Y., 2018. Building a sustainable development model for China's poverty-stricken reservoir regions based on system dynamics. J. Clean. Prod. 176, 535-554.

Corrado, S., Castellani, V., Zampori, L., Sala, S., 2018. Systematic analysis of secondary life cycle inventories when modelling agricultural production: a case study for arable crops. J. Clean. Prod. 172, 3990-4000.

Crenna, E., Sozzo, S., Sala, S., 2018. Natural biotic resources in LCA: towards an impact assessment model for sustainable supply chain management. J. Clean. Prod. 172, 3669-3684.

De Besi, M., McCormick, K., 2015. Towards a bioeconomy in Europe: national, regional and industrial strategies. Sustainability 7 (8), 10461-10478.

Dunnigan, L., Ashman, P.J., Zhang, X., Kwong, C.W., 2018. Production of biochar from rice husk: particulate emissions from the combustion of raw pyrolysis volatiles. J. Clean. Prod. 172, 1639-1645.

Egelyng, H., Romsdal, A., Hansen, H.O., Slizyte, R., Carvajal, A.K., Jouvenot, L. Hebrok, M., Honkapää, K., Wold, J.P., Seljåsen, R., Aursand, M., 2018. Cascading Norwegian co-streams for bioeconomic transition. J. Clean. Prod. 172, 3864-3873.

European Commission, 2012. Innovating for Sustainable Growth: a Bioeconomy for Europe. $\operatorname{COM}(2012) 60$ Final. Communication from the Commission to the European Parliament, the Council, the European Economic and Social Committee and the Committee of the Regions. European Commission, Brussels.

European Commission, 2014. COM/2014/015 Final, a Policy Framework for Climate and Energy in the Period from 2020 to 2030, pp. 1-18.

Ferrari, A.M., Pini, M., Sassi, D., Zerazion, E., Neri, P., 2018. Effects of grape quality on the environmental profile of an Italian vineyard for Lambrusco red wine production. J. Clean. Prod. 172, 3760-3769.

Fiore, A., Lardo, E., Montanaro, G., Laterza, D., Loiudice, C., Berloco, T., Dichio, B. Xiloyannis, C., 2018a. Mitigation of global warming impact of fresh fruit production through climate smart management. J. Clean. Prod. 172, 3634-3643.

Fiore, M., Spada, A., Contò, F., Pellegrini, G., 2018b. GHG and cattle farming: COassessing the emissions and economic performances in Italy. J. Clean. Prod. 172, 3704-3712.

Freire, P.A., 2018. Enhancing innovation through behavioural stimulation: the use of 
behavioural determinants of innovation in the implementation of ecoinnovation processes in industrial sectors and companies. J. Clean. Prod. 170, 1677-1687.

Gallo, C., Faccilongo, N., La Sala, P., 2018. Clustering analysis of environmental emissions: a study on Kyoto Protocol's impact on member countries. J. Clean. Prod. 172, 3685-3703.

Geissdoerfer, M., Savaget, P., Bocken, N.M.P., Hutlink, E.J., 2016. The circular economy - a new sustainability paradigm? J. Clean. Prod. 143, 757-768.

Giungato, P., Barbieri, P., Cozzutto, S., Licen, S., 2018. Sustainable domestic burning of residual biomasses from the Friuli Venezia Giulia region. J. Clean. Prod. 172, 3841-3850.

Goglio, P., Smith, W.N., Grant, B.B., Desjardins, R.L., Gao, X., Hanis, K., Tenuta, M. Campbell, C.A., McConkey, B.G. Nemecek, T., Burgess, P.., 2018b. A comparison of methods to quantify greenhouse gas emissions of cropping systems in LCA J. Clean. Prod. 172, 4010-4017.

Goglio, P., Smith, W.N., Grant, B.B., Desjardins, R.L., McConkey, B.G., Campbell, C.A., Nemecek, T., 2015. Accounting for soil carbon changes in agricultural life cycle assessment (LCA): a review. J. Clean. Prod. 104, 23-39.

Goglio, P., Smith, W.N., Worth, D.E., Grant, B.B., Desjardins, R.L., Chen, W., Tenuta, M. McConkey, B.G., Williams, A., Burgess, P., 2018a. Development of Crop.LCA, an adaptable screening life cycle assessment tool for agricultural systems: a Canadian scenario assessment. J. Clean. Prod. 172, 3770-3780.

González-García, S., Gullón, B., Moreira, M.T., 2018. Environmental assessment of biorefinery processes for the valorization of lignocellulosic wastes into oligosaccharides. J. Clean. Prod. 172, 4066-4073.

Hagman, L., Blumenthal, A., Eklund, M., Svensson, N., 2018. The role of biogas solutions in sustainable biorefineries. J. Clean. Prod. 172, 3982-3989.

Hildebrandt, J., Bezama, A., Thrän, D., 2017. Cascade use indicators for selected biopolymers: are we aiming for the right solutions in the design for recycling of bio-based polymers? Waste Manag. Res. 35 (4), 367-378.

Hou, Y., Velthof, G.L., Case, S.D.C., Oelofse, M., Grignani, C., Balsari, P., Zavattaro, L. Gioelli, F., Bernal, M.P., Fangueiro, D., Trindade, H., Jensen, L.S., Oenema, O., 2018 Stakeholder perceptions of manure treatment technologies in Denmark, Italy, The Netherlands and Spain. J. Clean. Prod. 172, 1620-1630.

Huisingh, D., Zhang, Z., Moore, J.C., Qiao, Q., Li, Q., 2015. Recent advances in carbon emissions reduction: policies, technologies, monitoring, assessment and modelling. J. Clean. Prod. 103,1-12.

Hurmekoski, E., Pykäläinen, J., Hetemäki, L., 2018. Long-term targets for green building: explorative Delphi backcasting study on wood-frame multi-story construction in Finland. J. Clean. Prod. 172, 3644-3654.

Husmann, K., Rumpf, S., Nagel, J., 2018. Biomass functions and nutrient contents of European beech, oak, sycamore maple and ash and their meaning for the biomass supply chain. J. Clean. Prod. 172, 4044-4056.

Ingrao, C., Bacenetti, J., Bezama, A., Blok, V., Geldermann, J., Goglio, P., Koukios, E.G. Lindner, M., Nemecek, T., Siracusa, V., Zabaniotou, A., Huisingh, D., 2016. Agricultural and forest biomass for food, materials and energy: bio-economy as the cornerstone to cleaner production and more sustainable consumption patterns for accelerating the transition towards equitable, sustainable, post fossil-carbon societies. J. Clean. Prod. 117, 4-6.

Ingrao, C., Faccilongo, N., Di Gioia, L., Messineo, A., 2018. Food waste recovery into energy in a circular economy perspective: a comprehensive review of aspects related to plant operation and environmental assessment. J. Clean. Prod. 184 $869-892$.

Jürges, N., Hansjürgens, B., 2018. Soil governance in the transition towards a sustainable bioeconomy - a review. J. Clean. Prod. 170, 1628-1639.

Karabulut, A.A., Crenna, E., Sala, S., Udias, A., 2018. A proposal for integration of the ecosystem-water-food-land-energy (EWFLE) nexus concept into life cycle assessment: a synthesis matrix system for food security. J. Clean. Prod. 172, 3874-3889.

Karliczek, A., 2018. Speech by Anja Karliczek, Federal Minister of Education and Research, on the Occasion of the Global Bioeconomy Summit 2018 in Berlin on Wednesday, 19 April 2018. Available at: http://gbs2018.com/fileadmin/gbs2018 Presentations/Karliczek_190418_engl.pdf.

Keshavarz Afshar, R., Lin, R., Mohammed, Y.A., Chen, C., 2018. Agronomic effects of urease and nitrification inhibitors on ammonia volatilization and nitrogen utilization in a dryland farming system: field and laboratory investigation. J. Clean. Prod. 172, 4130-4139.

Koukios, E., Monteleone, M., Texeira Carrondo, M.J., Charalambous, A., Girio, F., López Hernández, E. Mannelli, S., Parajó, J.C., Polycarpou, P., Zabaniotou, A. 2018. Targeting sustainable bioeconomy: a new development strategy for Southern European countries. The Manifesto of the European Mezzogiorno. J. Clean. Prod. 172, 3931-3941.

Lewandowski, I., 2015. Securing a sustainable biomass supply in a growing bioeconomy. Glob. Food Sec. 6, 34-42.

Lopes, C., Antelo, L.T., Franco-Uría, A., Alonso, A.A., Pérez-Martín, R., 2018a. Chitin production from crustacean biomass: sustainability assessment of chemical and enzymatic processes. J. Clean. Prod. 172, 4140-4151.

Lopes, J., Medeiros, D.L., Kiperstok, A., 2018b. Combining cleaner production and life cycle assessment for reducing the environmental impacts of irrigated carrot production in Brazilian semi-arid region. J. Clean. Prod. 170, 924-939.

Lovarelli, D., Ingrao, C., Fiala, M., Bacenetti, J., 2018. Beyond the Water Footprint: a new framework proposal to assess freshwater environmental impact and consumption. J. Clean. Prod. 172, 4189-4199.

Lozano, F.J., Lozano, R., 2018. Assessing the potential sustainability benefits of agricultural residues: biomass conversion to syngas for energy generation or to chemicals production. J. Clean. Prod. 172, 4162-4169.

Maalouf, C., Ingrao, C., Scrucca, F., Moussa, T, Bourdot, A., Tricase, C, Presciutti, A., Asdrubali, F., 2018. An energy and Carbon Footprint assessment upon the usage of hemp-lime concrete and recycled-PET façades for office facilities in France and Italy. J. Clean. Prod. 170, 1640-1653.

Martins, R., Cherni, J.A., Videira, N., 2018. 2MBio, a novel tool to encourage creative participatory conceptual design of bioenergy systems - the case of wood fuel energy systems in south Mozambique. J. Clean. Prod. 172, 3890-3906.

McCormick, K., Kautto, N., 2013. The bio-economy in Europe: an overview. Sustainability 5 (6), 2589-2608.

Merli, R., Preziosi, M., Acampora, A., 2018. Sustainability experiences in the wine sector: toward the development of an international indicators system. J. Clean. Prod. 172, 3791-3805.

Mihai, F.-C., Ingrao, C., 2018. Assessment of biowaste losses through unsound waste management practices in rural areas and the role of home composting. J. Clean. Prod. 172, 1631-1638.

Millinger, M., Thrän, D., 2018. Biomass price developments inhibit biofuel investments and research in Germany: the crucial future role of high yields. J. Clean. Prod. 172, 1654-1663.

Murray, A., Skene, K., Haynes, K., 2017. The circular economy: an interdisciplinary exploration of the concept and application in a global context. J. Bus. Ethics 140 (3), 369-380.

Mustalahti, I., 2018. The Responsive Bioeconomy: the need for inclusion of citizens and environmental capability in the forest based bio-economy. J. Clean. Prod. $172,3781-3790$

Nakano, K., Shibahara, N., Nakai, T., Shintani, K., Komata, H., Iwaoka, M., Hattori, N., 2018. Greenhouse gas emissions from round wood production in Japan. J. Clean. Prod. 170, 1654-1664.

Noya, I., González-García, S., Bacenetti, J., Fiala, M., Moreira, M.T., 2018. Environmental impacts of the cultivation-phase associated with agricultural crops for feed production. J. Clean. Prod. 172, 3721-3733.

Paustian, K., Lehmann, J., Ogle, S., Reay, D., Robertson, G.P., Smith, P., 2016. Climatesmart soils. Nature 532, 49-57.

Pergola, M., Piccolo, A., Palese, A.M., Ingrao, C, Di Meo, V., Celano, G, 2018. A combined assessment of the energy, economic and environmental issues associated with on-farm manure composting processes: two case studies in South of Italy. J. Clean. Prod. 172, 3969-3981.

Philp, J., 2015. Balancing the bioeconomy: supporting biofuels and bio-based materials in public policy. Energy Environ. Sci. 8 (11), 3063-3068.

Polimeni, J.M., Iorgulescu, R.I., Mihnea, A., 2018. Understanding consumer motivations for buying sustainable agricultural products at Romanian farmers markets. J. Clean. Prod. 184, 586-597.

Presciutti, A., Asdrubali, F., Baldinelli, G., Rotili, A., Malavasi, M., Di Salvia, G., 2018. Energy and exergy analysis of glycerol combustion in an innovative flameless power plant. J. Clean. Prod. 172, 3817-3824.

Pülzl, H., Kleinschmit, D., Arts, B., 2014. Bioeconomy - an emerging meta-discourse affecting forest discourses? Scand. J. For. Res. 29 (4), 386-393.

Purkus, A., Gawel, E., Szarka, N., Lauer, M., Lenz, V., Ortwein, A., Tafarte, P., Eichhorn, M., Thrän, D., 2018a. Contributions of flexible power generation from biomass to a secure and cost-effective electricity supply-a review of potentials, incentives and obstacles in Germany. Energy Sustain. Soc. 8 https://doi.org/ 10.1186/s13705-018-0157-0, 18.

Purkus, A., Hagemann, N., Bedtke, N., Gawel, E., 2018b. Towards a sustainable innovation system for the German wood-based bioeconomy: implications for policy design. J. Clean. Prod. 172, 3955-3968.

Ramcilovic-Suominen, S., Pülzl, H., 2018. Sustainable development - a 'selling point' of the emerging EU bioeconomy policy framework? J. Clean. Prod. 172, 4170-4180.

Reißmann, D., Thrän, D., Bezama, A., 2018a. Hydrothermal processes as treatment paths for biogenic residues in Germany: a review of the technology, sustainability and legal aspects. J. Clean. Prod. 172, 239-252.

Reißmann, D., Thrän, D., Bezama, A., 2018b. How to Identify Suitable Ways for the Hydrothermal Treatment of Wet Bio-waste? a Critical Review and Methods Proposal. Waste Management \& Research. https://doi.org/10.1177/ $0734242 \times 18785735$.

Rockström, J., Steffen, W., Noone, K., Persson, Å., Chapin, F.S., Lambin, E.F. Lenton, T.M., Scheffer, M., Folke, C., Schellnhuber, H.J., Nykvist, B., de Wit, C.A., Hughes, T., van der Leeuw, S., Rodhe, H., Sörlin, S., Snyder, P.K., Costanza, R., Svedin, U., Falkenmark, M., Karlberg, L., Corell, R.W., Fabry, V.J., Hansen, J., Walker, B., Liverman, D., Richardson, K., Crutzen, P., Foley, J.A., 2009. A safe operating space for humanity. Nature 461, 472-475.

Rota, C., Pugliese, P., Hashem, S., Zanasi, C., 2018. Assessing the level of collaboration in the Egyptian organic and fair trade cotton chain. J. Clean. Prod. 170, 1665-1676.

Scarlat, N., Dallemand, J.-F., Monforti-Ferrario, F., Nita, V., 2015. The role of biomass and bioenergy in a future bioeconomy: policies and facts. Environ. Dev. 15, $3-34$.

Scheiterle, L., Ulmer, A., Birner, R., Pyka, A., 2018. From commodity-based value chains to biomass-based value webs: the case of sugarcane in Brazil's bioeconomy. J. Clean. Prod. 172, 3851-3863.

Senyolo, M.P., Long, T.B., Blok, V., Omta, O., 2018. How the characteristics of innovations impact their adoption: an exploration of climate-smart agricultural innovations in South Africa. J. Clean. Prod. 172, 3825-3840.

Shi, J., Visschers, V.H.M., Bumann, N., Siegrist, M., 2018. Consumers' climate-impact estimations of different food products. J. Clean. Prod. 172, 1646-1653. 
Siebert, A., Bezama, A., O'Keeffe, S., Thrän, D., 2018b. Social life cycle assessment: in pursuit of a framework for assessing wood-based products from bioeconomy regions in Germany. Int. J. Life Cycle Assess. 23 (3), 651-662.

Siebert, A., Bezama, A., O'Keeffe, S., Thrän, D., 2018c. Social life cycle assessment indices and indicators to monitor the social implications of wood-based products. J. Clean. Prod. 172, 4074-4084.

Siebert, A., O'Keeffe, S., Bezama, A., Zeug, W., Thrän, D., 2018a. How not to compare apples and oranges: generate context-specific performance reference points for a social life cycle assessment model. J. Clean. Prod. https://doi.org/10.1016/ j.jclepro.2018.06.298.

Simha, P., Zabaniotou, A., Ganesapillai, M., 2018. Continuous urea-nitrogen recycling from human urine: a step towards creating a human excreta based bio-economy. J. Clean. Prod. 172, 4152-4161.

Spierling, S., Knüpffer, E., Behnsen, H., Mudersbach, M., Krieg, H., Springer, S., Albrecht, S., Herrmann, C., Endres, H.-J., 2018. Bio-based plastics - a review of environmental, social and economic impact assessments. J. Clean. Prod. 185, 476-491.

Szarka, N., Eichhorn, M., Kittler, R., Bezama, A., Thrän, D., 2017. Interpreting longterm energy scenarios and the role of bioenergy in Germany. Renew. Sustain. Energy Rev. 68 (2), 1222-1233.

Szarka, N., Wolfbauer, J., Bezama, A., 2018. A systems dynamics approach for supporting regional decisions on the energetic use of regional biomass residues. Waste Manag. Res. 36 (4), 332-341.

Thonemann, N., Schumann, M., 2018. Environmental impacts of wood-based products under consideration of cascade utilisation: a systematic literature review. J. Clean. Prod. 172, 4181-4188.

Thrän, D., Bezama, A., 2017. The knowledge-based bioeconomy and its impact in our working field. Waste Manag. Res. 35 (7), 689-690.

Tricase, C., Lamonaca, E., Ingrao, C., Bacenetti, J., Lo Giudice, A., 2018. A comparative Life Cycle Assessment between organic and conventional barley cultivation for sustainable agriculture pathways. J. Clean. Prod. 172, 3747-3759.
UNEP, 2011. Towards a Green Economy: Pathways to Sustainable Development and Poverty- Eradication. United Nations Environment Programme.

Valente, M., Chaves, C., 2018. Perceptions and valuation of GM food: a study on the impact and importance of information provision. J. Clean. Prod. 172, 4110-4118.

van Renssen, S., 2014. A bioeconomy to fight climate change. Nat. Clim. Change 4 951-953.

Varela-Candamio, L., Calvo, N., Novo-Corti, I., 2018. The role of public subsidies for efficiency and environmental adaptation of farming: a multi-layered business model based on functional foods and rural women. J. Clean. Prod. 183, 555-565.

Vaskan, P., Pachón, E.R., Gnansounou, E., 2018. Techno-economic and life-cycle assessments of biorefineries based on palm empty fruit bunches in Brazil. J. Clean. Prod. 172, 3655-3668.

Verbong, G., Geels, F., 2007. The ongoing energy transition: lessons from a sociotechnical, multi-level analysis of the Dutch electricity (1960-2004). Energy Pol. 32, 1025-1037.

Towards a Sustainable European Forest-based Bioeconomy - Assessment and the Way Forward. What Science Can Tell Us. In: Winkel, G. (Ed.), 2017, vol. 8. European Forest Institute, Joensuu, p. 160.

Zabaniotou, A., Kamaterou, P., Kachrimanidou, V., Vlysidis, A., Koutinas, A., 2018. Taking a reflexive TRL3-4 approach to sustainable use of sunflower meal for the transition from a mono-process pathway to a cascade biorefinery in the context of Circular Bioeconomy. J. Clean. Prod. 172, 4119-4129.

Zucali, M., Bacenetti, J. Tamburini, A., Nonini, L., Sandrucci, A., Bava, L., 2018. Environmental impact assessment of different cropping systems of homegrown feed for milk production. J. Clean. Prod. 172, 3734-3746.

Zucaro, A., Forte, A., Faugno, S., Impagliazzo, A., Fierro, A., 2018. Effects of ureafertilization rates on the environmental performance of giant reed lignocellulosic feedstock produced for biorefinery purpose. J. Clean. Prod. 172, 4200-4211.

Zwier, J., Blok, V., Lemmens, P., Geerts, R.-J., 2015. The ideal of a zero-waste humanity: philosophical reflections on the demand for a bio-based economy. J. Agric. Environ. Ethics 28 (2), 353-374. 